University of Nebraska - Lincoln

DigitalCommons@University of Nebraska - Lincoln

Agronomy \& Horticulture -- Faculty Publications

Agronomy and Horticulture Department

March 2002

\title{
Biosolids as Nitrogen Source for Irrigated Maize and Rainfed Sorghum
}

\author{
Darren L. Binder \\ University of Nebraska-Lincoln, dbinder1@unl.edu \\ Achim Dobermann \\ University of Nebraska-Lincoln \\ Donald H. Sander \\ University of Nebraska-Lincoln \\ Kenneth G. Cassman \\ University of Nebraska-Lincoln, kcassman1@unl.edu
}

Follow this and additional works at: https://digitalcommons.unl.edu/agronomyfacpub

Part of the Plant Sciences Commons

Binder, Darren L.; Dobermann, Achim; Sander, Donald H.; and Cassman, Kenneth G., "Biosolids as Nitrogen Source for Irrigated Maize and Rainfed Sorghum" (2002). Agronomy \& Horticulture -- Faculty Publications. 104.

https://digitalcommons.unl.edu/agronomyfacpub/104

This Article is brought to you for free and open access by the Agronomy and Horticulture Department at DigitalCommons@University of Nebraska - Lincoln. It has been accepted for inclusion in Agronomy \& Horticulture -Faculty Publications by an authorized administrator of DigitalCommons@University of Nebraska - Lincoln. 


\title{
Biosolids as Nitrogen Source for Irrigated Maize and Rainfed Sorghum
}

\author{
Darren L. Binder, Achim Dobermann,* Donald H. Sander, and Kenneth G. Cassman
}

\begin{abstract}
We quantified effects of anaerobically digested sewage sludge (biosolids) on yield, $\mathrm{N}$ use efficiency, and soil $\mathrm{NO}_{3}$ over a period of 4 yr. Field experiments with five biosolids rates and six $\mathbf{N}$ rates were conducted at two sites on a silty clay loam soil: one with irrigated maize (Zea mays L.) and another site with rainfed sorghum (Sorghum bicolor $\mathbf{L}$.). Biosolids rates for achieving maximum yields in the year of application were $62 \mathrm{Mg} \mathrm{ha}^{-1}$ (441 $\mathrm{kg}_{\text {organic }} \mathrm{N} \mathrm{ha}^{-1}$ ) on irrigated maize and $36 \mathrm{Mg} \mathrm{ha}^{-1}\left(257 \mathrm{~kg}\right.$ organic $\left.\mathrm{N} \mathrm{ha}^{-1}\right)$ on rainfed sorghum. At those rates, the increase in relative yield (RY) was $33 \%$ in the year of application, $21 \%$ in the second year, $14 \%$ in the third year, and $9 \%$ in the fourth year. Approximately 40, 20, 10, and 5\% of the total biosolids- $\mathrm{N}$ was recovered by the crops in the first, second, third, and fourth year, respectively. In irrigated maize, use efficiency of biosolids- $\mathbf{N}$ decreased with increasing biosolids rate, but was similar to that of fertilizer-N. In rainfed sorghum, use efficiency of biosolids$\mathrm{N}$ was lower than that of fertilizer-N. Little $\mathrm{NO}_{3}$ accumulated in soil when biosolids were applied at the recommended rate, but application in excess of that required for maximum yield increased $\mathrm{NO}_{3}$ accumulation in soil. The cumulative $\mathbf{N}$ fertilizer value of a biosolids application at the optimal rate was $\$ 136 \mathrm{ha}^{-1}$ for maize and $\$ 68 \mathrm{ha}^{-1}$ for sorghum. Biosolids had a total fertilizer-N replacement value of \$1.9 to 2.2 $\mathrm{Mg}^{-1}$ biosolids. Recommendations for biosolids use should be based on the total $\mathbf{N}$ input and its cumulative plant recovery and leaching potential across a 4-yr period.
\end{abstract}

$\mathrm{I}$ N NEBRASKA, $90 \%$ of anaerobically digested sewage sludge (biosolids) is land-applied (Goldstein, 1997). The potential benefits of land-applying biosolids in agricultural production are well documented (Kelling et al., 1977a; Lerch et al., 1990; Pierzynski, 1994; Sullivan et al., 1997). However, the economic costs and benefits to farmers utilizing biosolids as well as the long-term nutrient availability, plant response, and environmental impact of using biosolids on agricultural lands were identified as areas that needed more research (Oberle and Keeney, 1994). The potential environmental hazard most frequently associated with biosolids nutrients is excessive movement of $\mathrm{NO}_{3}$ from soil to groundwater (Keeney, 1989) or excessive accumulation of $\mathrm{P}$ or other elements. More reliable predictions, especially for local soil and climatic conditions, of the overall nutrient value, the N-supplying capacity, and crop yield response of biosolids, are required.

On average, $\approx 80 \%$ of the total $\mathrm{N}$ in biosolids is found in organic forms and $20 \%$ in mineral forms (Sommers, 1977). Previous studies have demonstrated that large rates of biosolids application to agricultural land can rapidly increase soil $\mathrm{NO}_{3}$ leaching (Hinesly et al., 1972; Stewart et al., 1975; Kelling et al., 1977b) and influence

D.L. Binder, A. Dobermann, D.H. Sander, and K.G. Cassman, Dep. of Agronomy and Horticulture, Univ. of Nebraska, P.O. Box 830915 Lincoln, NE 68583-0915. Contribution of the Nebraska Agric. Exp. Stn. Scientific Journal Series Paper no. 13145. *Corresponding author (adobermann2@unl.edu).

Published in Soil Sci. Soc. Am. J. 66:531-543 (2002). soil $\mathrm{N}$ supply and crop yields for several years after application (Kelling et al., 1977a; Boyle and Paul, 1989). Therefore, the proper management of cropland receiving biosolids by either high-rate single applications or repeated lower rate applications depends on the initial mineral $\mathrm{N}$ concentration, the rate at which biosolids organic matter is decomposed, the type of crop grown, and the target crop yield.

Mineralization of biosolids- $\mathrm{N}$ has been widely studied, especially in laboratory incubations. There are fewer studies that determined the residual value of biosolids under field conditions. Laboratory incubations have shown that mineralization of organic $\mathrm{N}$ from biosolids applied to soil follows first order kinetics (Parker and Sommers, 1983; Lindemann and Cardenas, 1984; Chae and Tabatabai, 1986). Although decay series measurements have been adapted by many states as a means to predict $\mathrm{N}$ mineralization from animal manure (Mathers and Goss, 1979; Nelson and Shapiro, 1989; Klausner et al., 1994), there is no entirely satisfactory procedure for this. As a rule of thumb, it was proposed that $\approx 20$, 10 , and $5 \%$ of the biosolids organic $\mathrm{N}$ is mineralized in the first, second, and third year, respectively (USEPA, 1995). However, actual field mineralization rates are much more variable, particularly depending on biosolids composition, soil type, soil temperature, and moisture content (Gilmour and Gilmour, 1980; Sims and Boswell, 1980; Artiola and Pepper, 1992; Barbarick et al., 1996). For example, in Wisconsin, 15 to 20, 6, and $4 \%$, of the biosolids organic $\mathrm{N}$ was mineralized in the first, second, and third year after application (Keeney et al., 1975). Another study found a decay series of 45,25 to 30 , and 10 to $15 \%$ of biosolids $\mathrm{N}$ mineralization in the $3-\mathrm{yr}$ period following application (Kelling et al., 1977b). Therefore, the differences in soil, climate, biosolids composition, and management factors require more specific estimates for different climatic regions or different cropping systems.

In this paper we address the issue of how to manage biosolids in two different arable cropping systems to sustain high yields and profits and minimize negative environmental effects. The specific objectives of our study were to quantify the yield response to biosolids$\mathrm{N}$ for irrigated maize and rainfed sorghum in eastern Nebraska, to assess $\mathrm{N}$ use efficiency of biosolids- $\mathrm{N}$, and to evaluate effects of biosolids application on soil $\mathrm{NO}_{3}$ dynamics.

\section{MATERIALS AND METHODS}

\section{Site Characteristics and Experimental Design}

This study was conducted from 1996 to 1999 at two onfarm locations close to Lincoln, NE. Although the two sites were $\approx 8 \mathrm{~km}$ apart, the soil at both sites was a Sharpsburg silty

Abbreviations: $\mathrm{AE}_{\mathrm{N}}$, agronomic efficiency of applied $\mathrm{N} ; \mathrm{RE}_{\mathrm{N}}$, apparent recovery efficiency of applied N; RY, relative yield. 
Table 1. Initial soil properties at the irrigated maize and rainfed sorghum locations. $\dagger$

\begin{tabular}{|c|c|c|}
\hline & $\begin{array}{c}\text { Irrigated maize } \\
\text { site }\end{array}$ & $\begin{array}{c}\text { Rainfed sorghum } \\
\text { site }\end{array}$ \\
\hline CEC, $\mathbf{c m o l}_{\mathrm{c}} \mathbf{k g}^{-1}$ & $\mathbf{3 7 . 0} \pm \mathbf{3}$ & $35.0 \pm 2$ \\
\hline $\mathbf{E C}, \mathbf{d S} \mathbf{m}^{-1}$ & $0.2 \pm 0.01$ & $\mathbf{0 . 2} \pm \mathbf{0 . 0 1}$ \\
\hline pH & $5.9 \pm 0.1$ & $5.7 \pm \mathbf{0 . 1}$ \\
\hline Soil organic $\mathrm{C}, \mathrm{g} \mathrm{kg}^{-1}$ & $15.1 \pm 0.9$ & $12.2 \pm 1.0$ \\
\hline \multicolumn{3}{|l|}{$\mathrm{NO}_{3}-\mathrm{N}, \mathrm{mg} \mathrm{kg}^{-1}$} \\
\hline $0-15 \mathrm{~cm}$ & $8.7 \pm \mathbf{2 . 0}$ & $10.5 \pm 0.4$ \\
\hline $15-30 \mathrm{~cm}$ & $5.6 \pm 2.0$ & $1.4 \pm 0.2$ \\
\hline $30-60 \mathrm{~cm}$ & $1.9 \pm 0.4$ & $1.1 \pm 0.1$ \\
\hline $60-90 \mathrm{~cm}$ & $1.3 \pm 0.2$ & $1.2 \pm 0.1$ \\
\hline $90-120 \mathrm{~cm}$ & $1.9 \pm 0.2$ & $1.0 \pm 0.1$ \\
\hline $120-150 \mathrm{~cm}$ & $2.7 \pm \mathbf{0 . 2}$ & $1.3 \pm 0.1$ \\
\hline P-Bray 1, mg kg-1 & $12 \pm 6$ & $18 \pm 2$ \\
\hline $\mathrm{K}-\mathrm{NH}_{4} \mathrm{OAc}, \mathrm{mg} \mathrm{kg}^{-1}$ & $306 \pm 8$ & $394 \pm 14$ \\
\hline $\mathrm{Zn}-D T P A+, \mathrm{mg} \mathrm{kg}^{-1}$ & $0.9 \pm 0.2$ & $\mathbf{0 . 5} \pm \mathbf{0 . 1}$ \\
\hline
\end{tabular}

$\dagger$ Values shown are means and standard deviations of four (maize site) or three (sorghum site) replicate plots of the control treatment. Unless stated otherwise, they refer to the $0-$ to $15-\mathrm{cm}$ depth.

$†$ DTPA = diethylenetrinitrilopentaacetic acid. clay loam, (fine, smectitic, mesic Typic Argiudolls). Initial soil properties were similar at both sites (Table 1), except for slightly less organic matter content at the rainfed site. Continuous irrigated maize (Zea mays L.) and continuous rainfed sorghum (Sorghum bicolor L.) were grown for the duration of the experiment, one cropping system per site. Maize had been continuously grown at the irrigated location for the previous $15 \mathrm{yr}$. The rainfed sorghum site had previously been cropped to a sorghum-sorghum-soybean [Glycine max (L.) Merr.] cropping system until 1992. It then underwent a 3-yr fallow period until soybeans were grown in 1995, the year before the study took place.

Two experiments were established at each location, one with different rates of anaerobically digested biosolids as the sole $\mathrm{N}$ source and one with different fertilizer-N rates. Treatments in all experiments were arranged in a randomized complete block design with a plot consisting of four replicate blocks at the irrigated maize site and three replicate blocks at the rainfed sorghum site.

In the biosolids experiments, treatments included a control without biosolids and four rates of biosolids application. Each

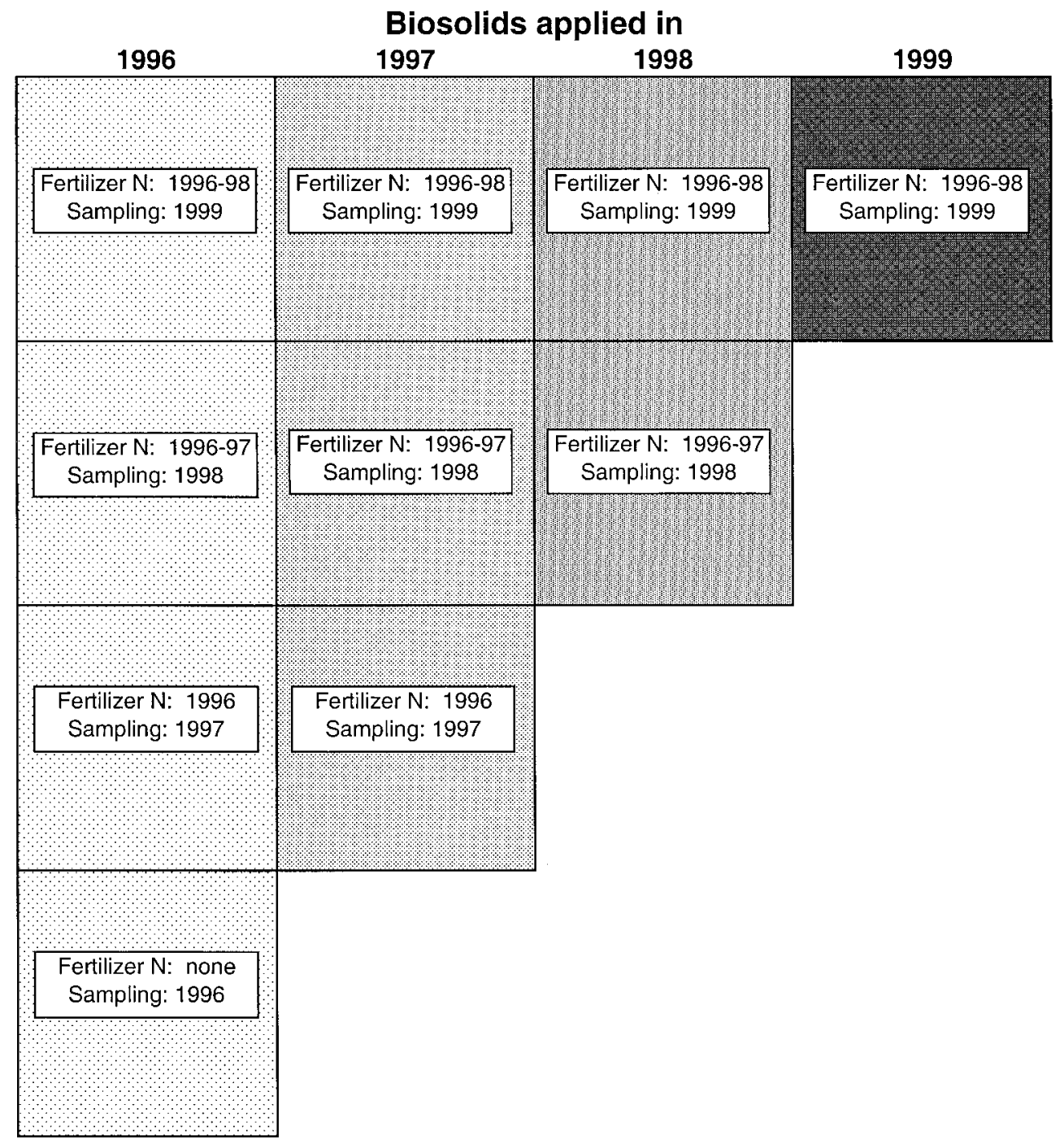

Fig. 1. Schematic display of the experimental design used to study the response of maize and sorghum to a single biosolids application. The graph only shows 4.5 - by $12-\mathrm{m}$ treatment plots for one replicate of one biosolids rate. In the actual design, the layout of all plots was randomized. Fertilizer-N was only applied in the years before biosolids application. 
year, biosolids were applied to new sets of treatment plots so there were no repeat applications in any treatment at either location (Fig. 1). Moreover, to study residual effects of a onetime biosolids application, each biosolids rate was applied to the same number of plots as the number of remaining measurement years. For example, in 1996, the same rate of biosolids was applied to four plots with one plot designated for being sampled in each year of the study (1996-1999). This was repeated in subsequent years at other locations in the field with each biosolids rate being applied to three plots in 1997, two plots in 1998, and one plot in 1999 (Fig. 1). The experiment included multiple control treatments, one per replicate block per year. All control plots not harvested in a particular year to assess biosolids response received a moderate rate of $90 \mathrm{~kg} \mathrm{~N} \mathrm{ha}^{-1}$ as $\mathrm{NH}_{4} \mathrm{NO}_{3}$ broadcast in spring. This was done to maintain the production from these plots so that the crop response to biosolids measured across a period of $4 \mathrm{yr}$ would not be exaggerated. Had the comparisons been made to a control that was continuously cropped for $4 \mathrm{yr}$ with no $\mathrm{N}$ additions, soil $\mathrm{N}$ depletion would have occurred so that the response to biosolids- $\mathrm{N}$ would have been artificially magnified.

In the mineral fertilizer experiments, six rates of $\mathrm{NH}_{4} \mathrm{NO}_{3}$ were applied from 0 to $225 \mathrm{~kg} \mathrm{~N} \mathrm{ha}^{-1}$ in $45-\mathrm{kg}$ intervals at the irrigated maize site and from 0 to $150 \mathrm{~kg} \mathrm{~N} \mathrm{ha}^{-1}$ in $30-\mathrm{kg}$ intervals at the rainfed sorghum site. Plot locations changed every year within the field. All plots used for the $\mathrm{N}$ response experiments received $90 \mathrm{~kg} \mathrm{~N}$ ha ${ }^{-1}$ in years preceding the actual $\mathrm{N}$ rate treatments to minimize variation in residual $\mathrm{N}$ effects that would affect estimates of $\mathrm{N}$ response curves and $\mathrm{N}$ efficiency in the subsequent crop grown. For example, plots used for $\mathrm{N}$ response studies in 1998 had received $90 \mathrm{~kg} \mathrm{~N}$ $\mathrm{ha}^{-1}$ in 1996 and 1997. Data of the fertilizer experiment were analyzed separately from the biosolids treatments.

\section{Biosolids Application}

Anaerobically digested biosolids applied in both experiments came from the City of Lincoln's Theresa Street wastewater treatment plant. The biosolids rates were intended to range from 0 to $100 \mathrm{Mg} \mathrm{ha}^{-1}$ of biosolids in $25-\mathrm{Mg}$ intervals at each location (fresh weight, equivalent to $0-18.2 \mathrm{Mg}$ dry weight ha ${ }^{-1}$ ). A John Deere 465 hydra-push manure spreader was used to apply the biosolids. The beater was run with ground speed power take off so that the biosolids were spread at a 2.1- to 2.3-m width. Two passes were made on each of the 12.2- by $4.6-\mathrm{m}$ plots for each application rate. The different biosolids rates were achieved by restricting the hydraulic fluid flow that regulated the speed at which the plunger panel moved. Each spreader load was struck level in an effort to achieve reproducible rates. In 1996, the biosolids rates were determined by catching the amount applied on two tarps at each end of the plot. Calibration of the spreader was improved in subsequent years such that the rates were applied as originally intended in 1997 through 1999. The amount of $\mathrm{N}$ applied with each biosolids rate varied between years because the biosolids composition was not consistent even though it was from the same source (Table 2). Biosolids were incorporated by disking to a $10-\mathrm{cm}$ depth within $24 \mathrm{~h}$ of application.

Biosolids samples were taken from each site the day the biosolids were applied. Four $500 \mathrm{~mL}$ plastic bottles were filled with biosolids from each location. Each bottle represented a separate pile (truck load), with each bottle containing biosolids taken from six to eight sites on each pile. Samples were frozen until analysis. Methods for analysis included automated combustion for total $\mathrm{C}$, total Kjeldahl $\mathrm{N}$, steam distillation of a wet sample for $\mathrm{NH}_{3}-\mathrm{N}$, ion chromatography for $\mathrm{NO}_{3}-\mathrm{N}$, and $\mathrm{HNO}_{3}-\mathrm{H}_{2} \mathrm{SO}_{4}$ method for total P. On average, biosolids ap-

Table 2. Nitrogen use efficiencies of biosolids- $N$ in irrigated maize and rainfed sorghum, as affected by biosolids rate and year of biosolids application. Data shown refer to a single biosolids application and its immediate and residual effect on maize or sorghum over a sequence of one to four crops. Within each row, values of $A E_{N}$ and $R E_{N}$ refer to the year of biosolids application (first number) followed by years with residual response to biosolids.

\begin{tabular}{|c|c|c|c|c|c|c|c|c|c|c|c|c|c|c|c|c|c|}
\hline & \multirow[b]{2}{*}{ Year } & \multicolumn{4}{|c|}{ Biosolids Rate 1} & \multicolumn{4}{|c|}{ Biosolids Rate 2} & \multicolumn{4}{|c|}{ Biosolids Rate 3} & \multicolumn{4}{|c|}{ Biosolids Rate 4} \\
\hline & & 1996 & 1997 & 1998 & 1999 & 1996 & 1997 & 1998 & 1999 & 1996 & 1997 & 1998 & 1999 & 1996 & 1997 & 1998 & 1999 \\
\hline \multicolumn{18}{|c|}{$\underline{\text { Irrigated maize }}$} \\
\hline Biosolids amount, $\mathrm{Mg} \mathrm{ha}^{-1}$ & & 33 & 25 & 25 & 25 & 79 & 50 & 50 & $\mathbf{5 0}$ & 92 & 75 & 75 & 75 & 106 & 100 & 100 & 100 \\
\hline Organic-N, kg ha ${ }^{-1}$ & & 250 & 141 & 144 & 177 & 600 & 282 & 288 & 353 & 698 & 424 & 431 & 530 & 804 & 565 & 575 & 706 \\
\hline $\mathrm{NH}_{4}-\mathrm{N}, \mathrm{kg} \mathrm{ha}^{-1}$ & & 55 & 30 & 34 & 49 & 131 & 61 & 68 & 98 & 153 & 91 & 102 & 147 & 176 & 122 & 136 & 196 \\
\hline \multirow{5}{*}{$\begin{array}{l}\text { Agronomic efficiency of } \\
\text { biosolids-N, } \mathrm{kg} \mathrm{kg}^{-1}\end{array}$} & & & & & & & & & & & & & & & & & \\
\hline & 1st & 3.8 & 18.9 & 18.4 & 17.2 & 3 & 11.3 & 10 & 11.4 & 2.4 & 6.8 & 7.5 & 7.4 & 3.2 & 5.4 & 5 & 6.3 \\
\hline & 2nd & 6.9 & 9.5 & 8.9 & - & 4.9 & 5.8 & 8.7 & - & 2.7 & 3.9 & 8.3 & - & 4.2 & 4.3 & 7.8 & - \\
\hline & 3rd & 5.4 & 16 & - & - & 2 & 7.7 & - & - & 1.5 & 5.4 & - & - & 2 & 4.5 & - & - \\
\hline & 4th & 14.5 & - & - & - & 1.8 & - & - & - & 2.8 & - & - & - & 4.7 & - & - & - \\
\hline \multirow{5}{*}{$\begin{array}{l}\text { Apparent recovery efficiency } \\
\text { of biosolids-N, } \mathrm{kg} \mathrm{kg}^{-1} \S\end{array}$} & & & & & & & & & & & & & & & & & \\
\hline & 1st & 0.06 & 0.45 & 0.39 & 0.43 & 0.08 & 0.34 & 0.23 & 0.31 & 0.07 & 0.22 & 0.19 & 0.31 & 0.08 & 0.16 & 0.15 & 0.2 \\
\hline & 2nd & 0.09 & 0.09 & 0.22 & - & 0.09 & 0.09 & 0.18 & - & 0.06 & 0.06 & 0.19 & - & 0.11 & 0.08 & 0.17 & - \\
\hline & 3rd & 0.08 & 0.23 & - & - & 0.02 & 0.14 & - & - & 0.02 & 0.12 & - & - & 0.02 & 0.07 & - & - \\
\hline & 4th & 0.17 & - & - & - & 0.03 & - & - & - & 0.06 & - & - & - & 0.07 & - & - & - \\
\hline \multicolumn{18}{|c|}{$\underline{\text { Rainfed sorghum }}$} \\
\hline Biosolids amount, $\mathrm{Mg} \mathrm{ha}^{-1} \dagger$ & & 23 & 25 & 25 & 25 & 45 & $\mathbf{5 0}$ & $\mathbf{5 0}$ & 50 & 66 & 75 & 75 & 75 & 90 & 100 & 100 & 100 \\
\hline Organic-N, $\mathrm{kg} \mathrm{ha}^{-1}$ & & 156 & 164 & 122 & 185 & 297 & 329 & 244 & 371 & 438 & 493 & 366 & 556 & 603 & 657 & 488 & 742 \\
\hline $\mathrm{NH}_{4}-\mathrm{N}, \mathrm{kg} \mathrm{ha}^{-1}$ & & 32 & 33 & 36 & 48 & 61 & 65 & 73 & 97 & 89 & 98 & 109 & 145 & 123 & 131 & 146 & 193 \\
\hline \multirow{5}{*}{$\begin{array}{l}\text { Agronomic efficiency of } \\
\text { biosolids-N, kg kg-1 } \leftarrow\end{array}$} & & & & & & & & & & & & & & & & & \\
\hline & 1st & 7.9 & 9.1 & 12.1 & 7.6 & 4.4 & 9.1 & 11.8 & 6.6 & 0.1 & 5.4 & 8.8 & 6.7 & 1.4 & 4.4 & 6.4 & 5.5 \\
\hline & 2nd & 0.5 & 5 & 14.5 & - & 7.2 & 8.5 & 8.1 & - & 4.4 & 5.2 & 9.6 & - & 5.4 & 3.9 & 6.7 & - \\
\hline & 3rd & 9.5 & 10.3 & - & - & 6 & 4.2 & - & - & 4.9 & 8.0 & - & - & 4.2 & 4.3 & - & - \\
\hline & 4th & 2.8 & - & - & - & 5 & - & - & - & 2.1 & - & - & - & 2.0 & - & - & - \\
\hline \multirow{5}{*}{$\begin{array}{l}\text { Apparent recovery efficiency } \\
\text { of biosolids-N, } \mathbf{~ g ~ k g ~}^{-1} \S\end{array}$} & & & & & & & & & & & & & & & & & \\
\hline & 1st & 0.25 & 0.21 & 0.30 & 0.10 & 0.18 & 0.24 & 0.18 & 0.11 & 0.09 & 0.19 & 0.24 & 0.14 & 0.08 & 0.17 & 0.21 & 0.14 \\
\hline & 2nd & 0 & 0.07 & 0.19 & - & 0.23 & 0.16 & 0.10 & - & 0.14 & 0.15 & 0.17 & - & 0.17 & 0.15 & 0.14 & - \\
\hline & 3rd & 0.07 & 0.13 & - & - & 0.08 & 0.04 & - & - & 0.10 & 0.12 & - & - & 0.07 & 0.04 & - & - \\
\hline & 4th & 0.14 & - & - & - & 0.07 & - & - & - & 0.04 & - & - & - & 0.02 & - & - & - \\
\hline
\end{tabular}

$\dagger$ Fresh weight of biosolids. Average dry matter content was $182 \mathbf{g ~ k g}^{-1}$.

$+\mathbf{A E}_{\mathbf{N}}=\mathbf{k g}$ yield increase per kg organic + inorganic biosolids- $\mathbf{N}$ applied.

$\S \mathbf{R E}_{\mathrm{N}}=\mathbf{k g}$ increase in $\mathrm{N}$ uptake per $\mathrm{kg}$ organic + inorganic biosolids- $\mathrm{N}$ applied. 
plied in both experiments from 1996 to 1999 contained $185 \mathrm{~g}$ solids $\mathrm{kg}^{-1}$ fresh weight. The average dry matter composition was $271 \mathrm{~g} \mathrm{C} \mathrm{kg}^{-1}(\mathrm{SD}=31), 38 \mathrm{~g}$ organic $\mathrm{N} \mathrm{kg}^{-1}(\mathrm{SD}=5)$, $8.4 \mathrm{~g} \mathrm{NH}_{4}-\mathrm{N} \mathrm{kg}^{-1}(\mathrm{SD}=1.5), 0.02 \mathrm{~g} \mathrm{NO}_{3}-\mathrm{N} \mathrm{kg}^{-1}(\mathrm{SD}=0.02)$, $27.8 \mathrm{~g} \mathrm{P} \mathrm{kg}^{-1}(\mathrm{SD}=4.5), 3.8 \mathrm{~g} \mathrm{~K} \mathrm{~kg}^{-1}(\mathrm{SD}=1.8)$, and $37 \mathrm{~g}$ Fe $\mathrm{kg}^{-1}(\mathrm{SD}=11)$. Weekly analysis of biosolids samples in 1998 indicated that concentrations of other elements were below hazardous levels (USEPA, 1993). Biosolids on average contained $11 \mathrm{mg} \mathrm{As} \mathrm{kg}{ }^{-1}, 18 \mathrm{mg} \mathrm{Cd} \mathrm{kg}{ }^{-1}, 122 \mathrm{mg} \mathrm{Cr} \mathrm{kg}{ }^{-1}$, $770 \mathrm{mg} \mathrm{Cu} \mathrm{kg}{ }^{-1}, 87 \mathrm{mg} \mathrm{Pb} \mathrm{kg}{ }^{-1}, 0.005 \mathrm{mg} \mathrm{Hg} \mathrm{kg}{ }^{-1}, 22 \mathrm{mg} \mathrm{Mo}$ $\mathrm{kg}^{-1}, 98 \mathrm{mg} \mathrm{Ni} \mathrm{kg}{ }^{-1}, 6.1 \mathrm{mg} \mathrm{Se} \mathrm{kg}{ }^{-1}$, and $797 \mathrm{mg} \mathrm{Zn} \mathrm{kg}^{-1}$ (American Public Health Association, 1995).

\section{Field Management}

In 1996, a blanket dose of $60 \mathrm{~kg} \mathrm{P} \mathrm{ha}^{-1}$ was broadcast on all plots at both sites as triple superphosphate and $6 \mathrm{~kg} \mathrm{Zn}$ $\mathrm{ha}^{-1}$ was broadcast as $\mathrm{ZnSO}_{4}$ at the irrigated maize site. Because yields in the fertilizer experiment in 1996 suggested insufficient $\mathrm{P}$ supply, another $80 \mathrm{~kg} \mathrm{P} \mathrm{ha}^{-1}$ as triple superphosphate was broadcast and incorporated in the spring of 1997 to the irrigated maize site to ensure that $\mathrm{P}$ was not a limiting factor for studying crop response to biosolids and fertilizer$\mathrm{N}$. The cooperators performed all other farm operations such as tillage, planting, pest management, and irrigation. The soil was typically disked at a $6-$ to $10-\mathrm{cm}$ depth or field cultivated two times before planting for weed control, fertilizer and biosolids incorporation, and seed bed preparation at both sites.

At the irrigated site, maize hybrid Pioneer 3489 was planted in 1996 and 1997 at 65000 plants ha ${ }^{-1}$ in rows spaced 76 cm apart. In 1998 and 1999, maize hybrids were chosen for herbicide resistance rather than yield potential in order to control Shattercane (S. bicolor). A NC+ IR hybrid was planted in 1998 and Asgrow 686RR (Roundup ready) maize in 1999. The harvested population densities were 61, 54, 55, and 50 thousand plants ha ${ }^{-1}$ in 1996 through 1999, respectively. Year-to-year variations in maize yields were largely due to variation in climate. Malfunction of the irrigation system along with higher than normal air temperature during maize pollination was a major cause of lower yields in 1999.

Sorghum hybrid NC+7R37E was planted at $5.6 \mathrm{~kg} \mathrm{ha}^{-1}$ during all 4 yr of the study in $76-\mathrm{cm}$ rows. Crop emergence was uniform for all years. However, the lack of a killing frost until late in the season resulted in many tillers producing grain in 1996. Approximately 150000 heads ha ${ }^{-1}$ were harvested in 1996 , compared with $\approx 125000$ in 1997 through 1999. Note that sorghum yields in unfertilized plots in 1999 were very low,

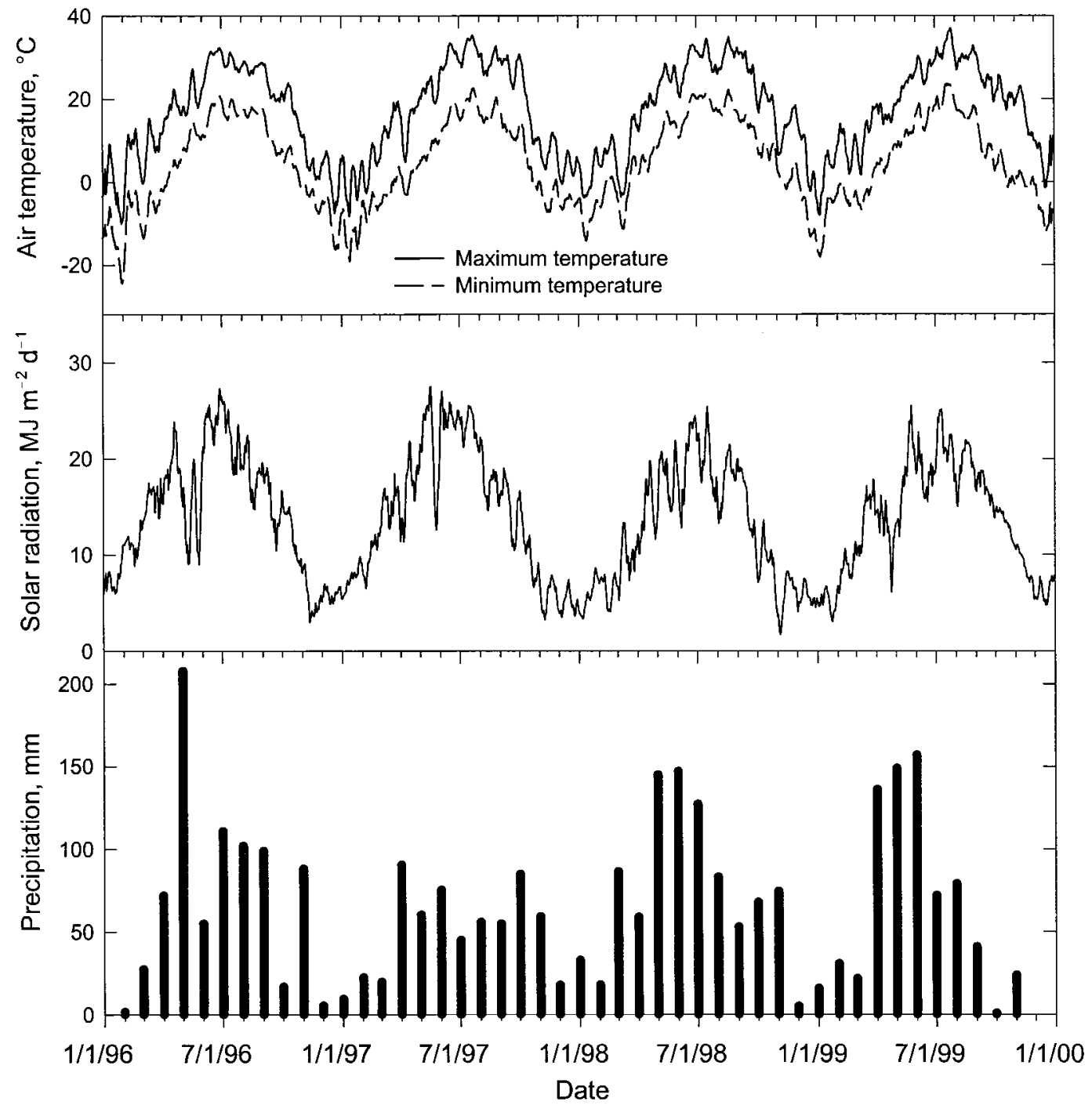

Fig. 2. Deviation of high and low air temperature, solar radiation, and monthly precipitation during 1996 to 1999 from the 15 -yr average at the Havelock Weather Station, Lancaster County, NE, based on 9-d moving averages. 
probably due to smaller soil $\mathrm{N}$ mineralization resulting from a cool spring and dry summer period (Fig. 2).

\section{Soil and Plant Sampling}

All soil and plant samples were collected from 4.6- by 12.2$\mathrm{m}$ sampling plots. Grain and stover samples at physiological maturity and all soil samples were taken from the middle two rows of each six-row plot. Soil samples were collected at the beginning of the experiment to determine the general soil properties. This was done by collecting four soil cores (40$\mathrm{mm}$ diameter) from each replication to a depth of $1.50 \mathrm{~m}$ in increments of 0 to $0.15,0.15$ to $0.30,0.30$ to $0.60,0.60$ to 0.90 , 0.90 to 1.20 , and 1.20 to $1.50 \mathrm{~m}$ to obtain one composite sample per depth and replicate plot. Soils were air-dried and ground to pass through a 2-mm sieve. Measurements followed standard methods and included electrical conductivity and $\mathrm{pH}(1: 1$ soil: $\mathrm{H}_{2} \mathrm{O}$ ), organic C (Walkley, 1947), $2 M \mathrm{KCl}$-extractable $\mathrm{NH}_{4}-\mathrm{N}$ and $\mathrm{NO}_{3}-\mathrm{N}$ (Mulvaney, 1996), $0.03 M \mathrm{NH}_{4} \mathrm{~F}+0.025$ $M \mathrm{HCl}$ extractable $\mathrm{P}$ (Bray and Kurtz, 1945), $1 M \mathrm{NH}_{4} \mathrm{O}$ acetate-extractable K (Brown and Warncke, 1988), and diethylenetrinitrilopentaacetic-extractable Zn (Lindsay and Norvell, 1978). Soil samples were also collected in the spring of 1997, the fall of 1997, and the fall of 1999 to determine the residual $\mathrm{N}$. Two soil cores were taken per plot to a depth of $1.50 \mathrm{~m}$ and divided by depth intervals as previously described. The soil cores were combined, air-dried at room temperature $\left(26{ }^{\circ} \mathrm{C}\right)$ and ground to pass through a 2-mm sieve. Samples were analyzed for $2 \mathrm{M} \mathrm{KCl}$-extractable $\mathrm{NH}_{4}-\mathrm{N}$ and $\mathrm{NO}_{3}-\mathrm{N}$ (Mulvaney, 1996) and total N (Yeomans and Bremner, 1991).

Grain was hand picked from two 3-m sections of the center two rows at physiological maturity. Stalks were then cut at soil surface from one of the 3-m sections for determination of dry matter and nutrient concentrations. The whole plant

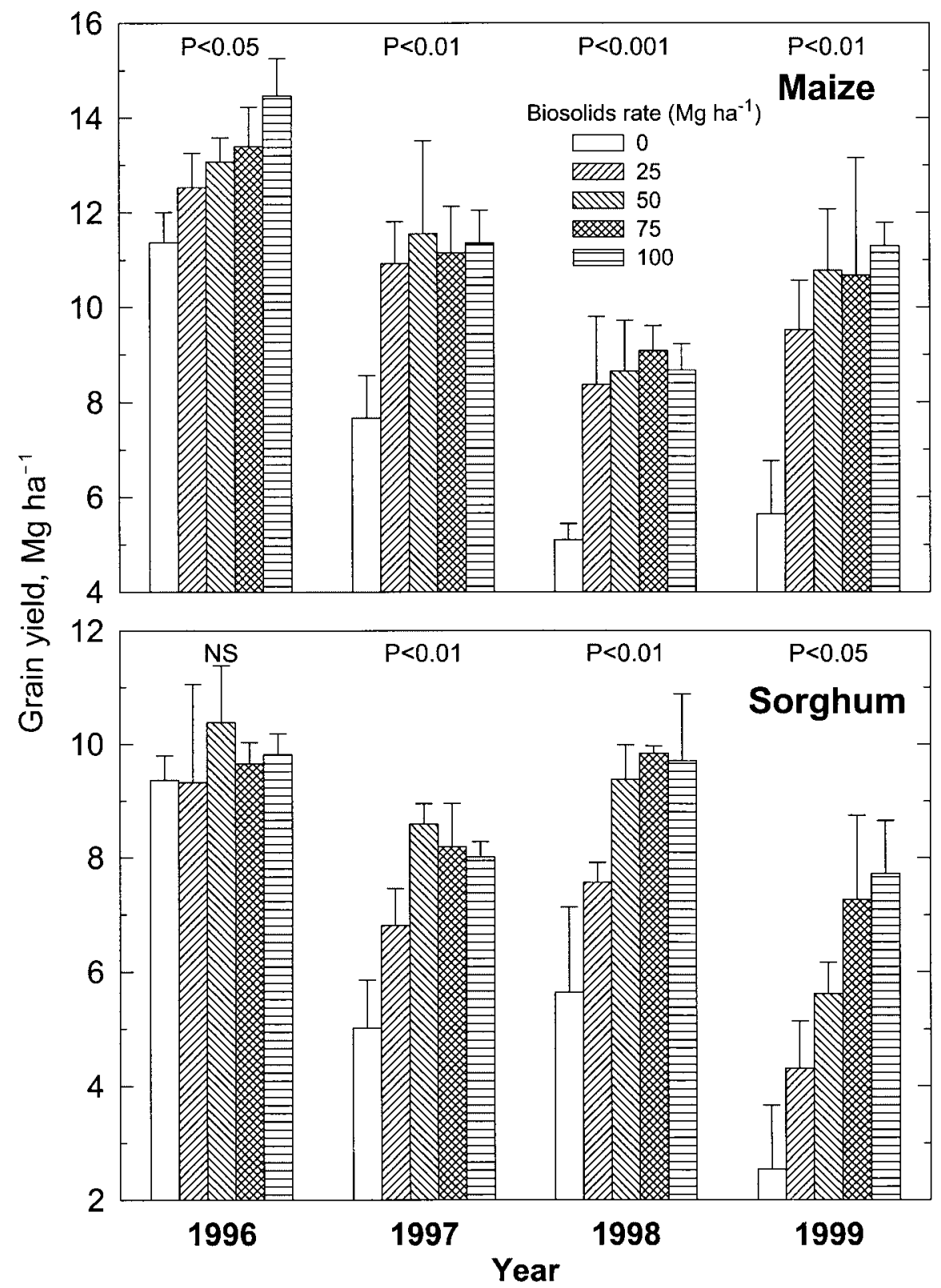

Fig. 3. Grain yield of irrigated maize and rainfed sorghum, as affected by the rate of applied biosolids in the year of application in 1996 to 1999 (Treatment means and standard deviation; $\boldsymbol{P}=$ probability of significant yield response). Biosolids rates shown in the legend refer to 1997 to 1999. In 1996, rates were $0,33,79,92$, and $106 \mathrm{Mg} \mathrm{ha}^{-1}$ for maize and $0,23,45,66$, and $90 \mathrm{Mg} \mathrm{ha}^{-1}$ for sorghum. 
sample was weighed, chopped, a 700 - to 1000 -g subsample taken and dried at $70{ }^{\circ} \mathrm{C}$, reweighed for moisture calculation, and ground. Maize grain was shelled, a 300- to 600-g subsample taken and dried at $70{ }^{\circ} \mathrm{C}$. Grain yields were reported on a $0.155 \mathrm{~g} \mathrm{~kg}^{-1}$ moisture basis. Total $\mathrm{N}$ content in plant samples was analyzed using an automated combustion method (McGeehan and Naylor, 1988).

\section{Calculations and Statistical Analysis}

Analysis of variance was conducted using PROC GLM of SAS (SAS Institute, 1988) to assess differences among the biosolids treatments. Data were analyzed as if each year of biosolids application was a separate experiment because the biosolids rates and the biosolids composition were not the same between years. In 1996, the experiments were analyzed as a randomized complete block with the five rates of biosolids and three to four replications, depending on the site. In 1997, the data were analyzed as if the biosolids applied in 1996 was a separate experiment from the biosolids applied in 1997. There was an analysis of variance for the 1996 applied biosolids and the 1997 applied biosolids for each site. In 1998, there were three ANOVAs, and in 1999 four ANOVAs, with comparisons only being made between biosolids applied in the same year.

Linear- and quadratic-plateau regression models were fitted to the experimental data to describe the relationship between $\mathrm{RY}$ and the amount of $\mathrm{N}$ applied from biosolids or fertilizer. For each data set, the model with the highest adjusted $r^{2}$ was identified and used in further data analysis. Nitrogen use efficiencies were estimated using the differences between $\mathrm{N}$-fertilized treatments and the unfertilized control. Terms used are $\mathrm{AE}_{\mathrm{N}}$, agronomic efficiency of applied $\mathrm{N}$ ( $\mathrm{kg}$ grain yield increase $\mathrm{kg}^{-1} \mathrm{~N}$ applied); and $\mathrm{RE}_{\mathrm{N}}$, apparent recovery efficiency of applied $\mathrm{N}$ ( $\mathrm{kg} \mathrm{N}$ taken up $\mathrm{kg}^{-1} \mathrm{~N}$ applied):

$$
A E_{N}=\left(G Y_{+N}-G_{0 N} / N\right)
$$

$$
\mathrm{RE}_{\mathrm{N}}=\left(\mathrm{UN}_{+\mathrm{N}}-\mathrm{UN}_{0 \mathrm{~N}}\right) / \mathrm{N}
$$

where GY is the grain yield $\left(\mathrm{kg} \mathrm{ha}^{-1}\right), \mathrm{UN}$ is the plant $\mathrm{N}$ accumulation in aboveground biomass $\left(\mathrm{kg} \mathrm{ha}^{-1}\right), \mathrm{N}$ is the amount of fertilizer or biosolids- $\mathrm{N}$ applied $\left(\mathrm{kg} \mathrm{ha}^{-1}\right)$ and $+\mathrm{N}$ and ${ }_{0 \mathrm{~N}}$ refer to treatments with and without $\mathrm{N}$ application, respectively. For biosolids treatments, $\mathrm{N}$ includes both organic- $\mathrm{N}$ and $\mathrm{NH}_{4}-\mathrm{N}$ contained in the biosolids.

\section{RESULTS AND DISCUSSION}

\section{Grain Yield, N uptake, and N Use Efficiency in the Year of Application}

From 1996 to 1999, the average maize yield in all + biosolids treatments was $11 \mathrm{Mg} \mathrm{ha}^{-1}$. Depending on the year and application rate, maize grain yields after biosolids application in spring increased by 1.2 to 5.7 $\mathrm{Mg} \mathrm{ha}^{-1}$, compared with the control without biosolids of fertilizer application (Fig. 3). Maize yields with biosolids application were similar to or exceeded those in fertilizer-N treatments in all 4 yr (Fig. 3, Table 3), suggesting that large amounts of biosolids-N were plant available in the first year. A more consistent maize yield response to applied biosolids across the $4 \mathrm{yr}$ was observed when yield was expressed on a relative basis (Fig. 4) and plotted against the rate of organic-N applied with biosolids. On average, $441 \mathrm{~kg}$ organic $\mathrm{N} \mathrm{ha}^{-1}$ in the applied biosolids was required to achieve the maximum relative grain yield of maize in the year of biosolids application (Table 4, Fig. 4). On the basis of an average biosolids content of $38 \mathrm{~g}$ organic $\mathrm{N} \mathrm{kg}^{-1}$ dry matter, this translates into an optimal rate for irrigated maize of $\approx 62 \mathrm{Mg} \mathrm{ha}^{-1}$ fresh biosolids (or $11.5 \mathrm{Mg} \mathrm{ha}^{-1}$ on dry weight basis).

Table 3. Grain yield and nitrogen use efficiencies of mineral fertilizer $\mathbf{N}$ in irrigated maize and rainfed sorghum as affected by $\mathbf{N}$ rate. Data shown refer to annual fertilizer-N applications on maize or sorghum grown in the year of application.

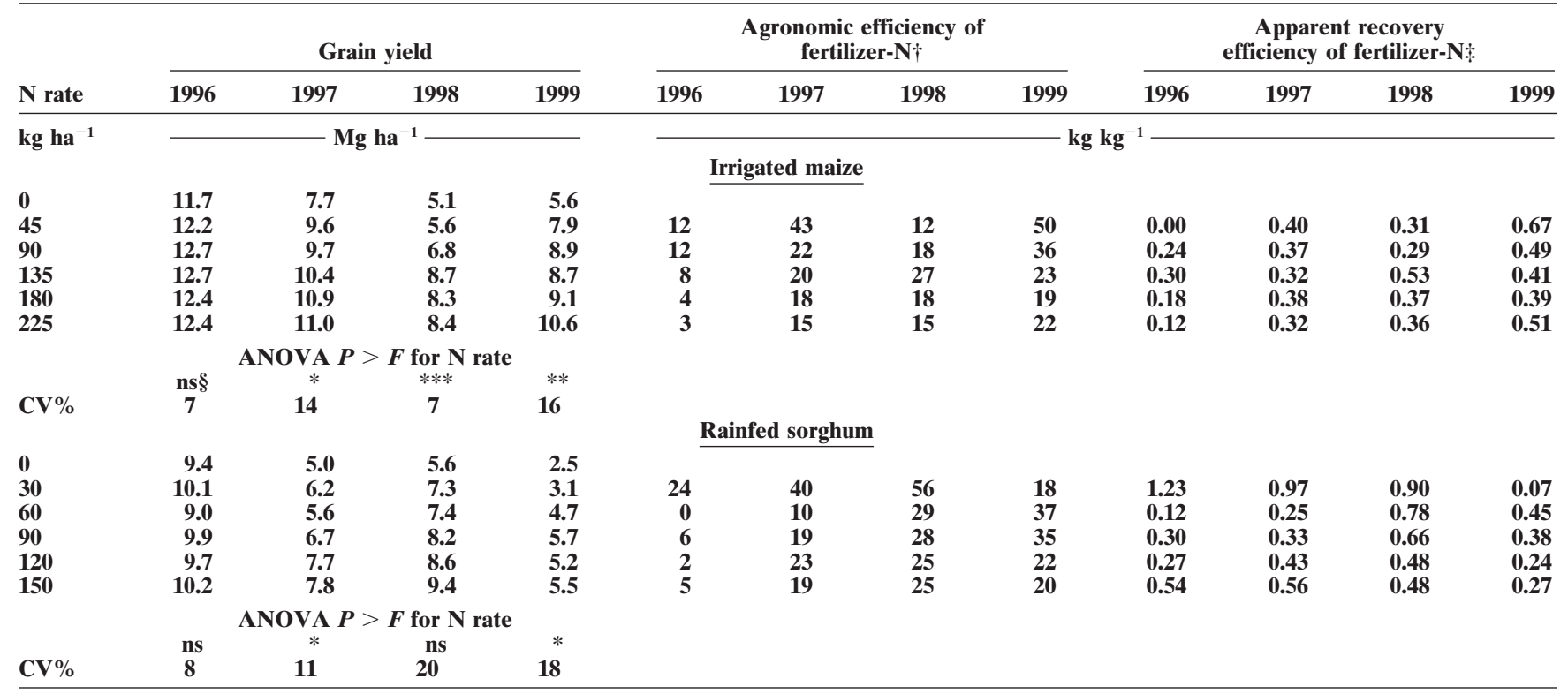

* Significant at the 0.05 probability level.

*** Significant at the 0.01 probability level.

$* * *$ Significant at the 0.001 probability level.

$\dagger \mathbf{A \mathbf { E } _ { \mathrm { N } }}=\mathbf{k g}$ yield increase per $\mathrm{kg}$ fertilizer- $\mathrm{N}$ applied.

$+\mathbf{R E}_{\mathbf{N}}=\mathbf{k g}$ increase in $\mathbf{N}$ uptake per $\mathrm{kg}$ fertilizer-N applied.

$\S \mathrm{ns}=$ not significant. 
Organic biosolids-N was used for estimating the optimal rate to eliminate variation caused by seasonal differences in biosolids- $\mathrm{N}$ content and rate of application and to also account for residual $\mathrm{N}$ resulting from mineralization of organic- $\mathrm{N}$ across time. Although there was a negative correlation between inorganic and organic $\mathrm{N}$ concentrations in the biosolids $\left(\mathrm{NH}_{4}-\mathrm{N}=3883-0.061\right.$ organic-N, $r=0.72$, both expressed as $\mathrm{mg} \mathrm{kg}^{-1}$ ), using total biosolids-N instead of organic-N resulted in a similar optimal biosolids rate (data not shown).

Sorghum grain yield increases due to biosolids application ranged from 0 to $5.2 \mathrm{Mg} \mathrm{ha}^{-1}$, as compared with the unfertilized control. At rates of 50 to $100 \mathrm{Mg}$ biosolids ha ${ }^{-1}$ (Fig. 3), sorghum yields were similar to or exceeded those measured in treatments receiving 120 to $150 \mathrm{~kg}$ fertilizer- $\mathrm{N} \mathrm{ha}^{-1}$ (Table 3). However, at the lowest rate, $25 \mathrm{Mg}$ biosolids $\mathrm{ha}^{-1}$, sorghum yields were $\approx 1.0$ $\mathrm{Mg} \mathrm{ha}^{-1}$ below the maximum yields achieved with 120 to $150 \mathrm{~kg}$ fertilizer-N ha ${ }^{-1}$. Without irrigation, relative rainfed sorghum yield response to biosolids was less consistent than that of irrigated maize (Fig. 4). In 1996, neither biosolids nor mineral fertilizer had a significant effect on sorghum grain yield. The lack of sorghum response in 1996 was likely due to the high residual soil $\mathrm{NO}_{3}$ and $\mathrm{N}$ mineralization resulting from the previous soybean crop, and the 3-yr fallow period before. Sorghum yield responses in 1997 and 1998 were similar and considered representative of more common rotations and climatic conditions for southeast Nebraska. In 1999, a year with low soil $\mathrm{N}$ supply due to cool weather, sorghum responded to much higher rates of biosolids up to the maximum of $100 \mathrm{Mg} \mathrm{ha}^{-1}$ (Fig. 4). For a typical sorghum crop, the optimal biosolids rate to maximize $\mathrm{RY}$ in the year of application was $257 \mathrm{~kg}$ organic $\mathrm{N} \mathrm{ha}^{-1}$ or $\approx 36 \mathrm{Mg} \mathrm{ha}^{-1}$ of fresh biosolids (Table 4). Sorghum did not respond to biosolids in 1996 due to reasons already discussed, but this was not considered typical since most fields do not undergo a 3-yr fallow period.

Plant $\mathrm{N}$ accumulation in the first year increased up to $\approx 75 \mathrm{Mg}$ biosolids ha ${ }^{-1}$ in maize (except in 1997) and through the whole range of biosolids rates in sorghum (Fig. 5). Climatic factors explain why the extra $\mathrm{N}$ taken

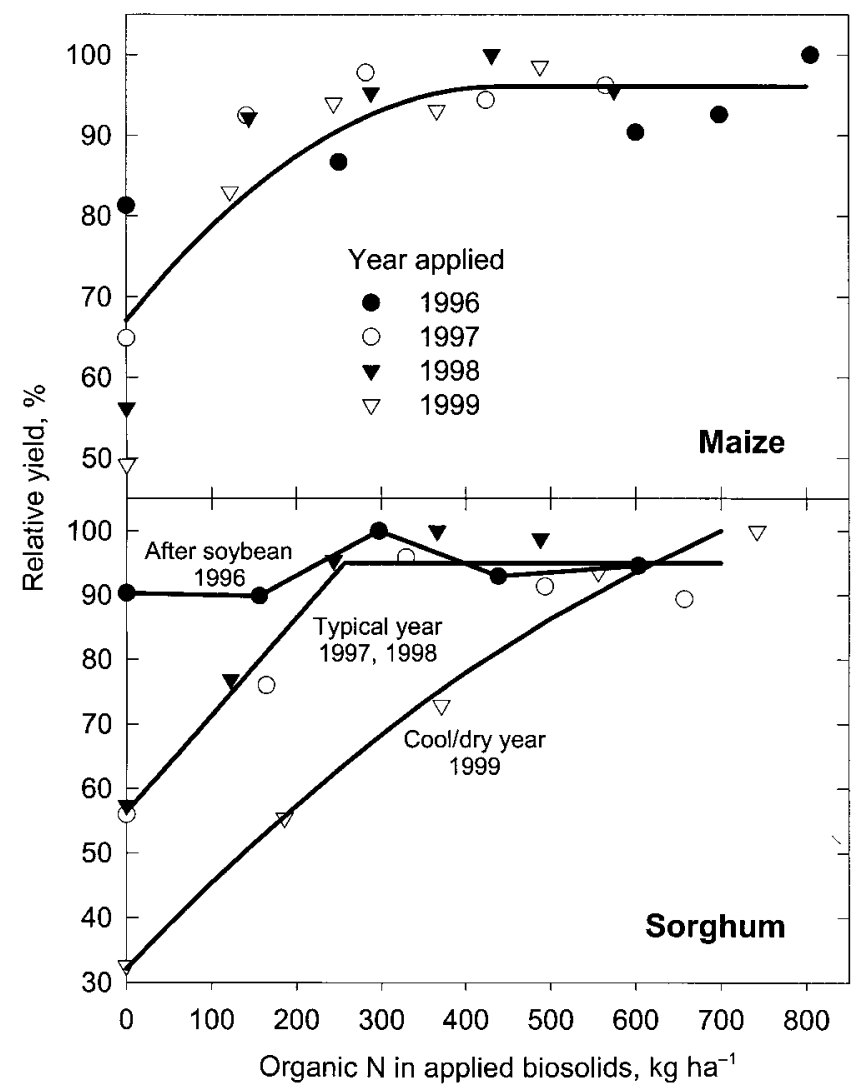

Fig. 4. Relative irrigated maize and rainfed sorghum yield response to the amount of organic $\mathrm{N}$ applied with biosolids in the year of biosolids application.

up by maize was not always translated into higher grain yield. For example, in 1999, total N uptake of maize was nearly $100 \mathrm{~kg} \mathrm{~N} \mathrm{ha}^{-1}$ greater than the average of the other 3 yr (Fig. 5), but all data points were below the average relationship between grain yield and $\mathrm{N}$ accumulation (Fig. 6). This indicates a situation of nutrient accumulation in the plant but restricted movement to the grain due to one or more other limiting factors such as climate, water stress, pests, or other nutrients (Janssen et al., 1990; Witt et al., 1999). In this case, the

Table 4. Regression models for predicting relative irrigated maize and rainfed sorghum response to biosolids for the year of biosolids application and the $3 \mathrm{yr}$ after application.

\begin{tabular}{|c|c|c|c|c|}
\hline Year $\dagger$ & Crop & $\mathbf{R Y} \ddagger$ & Organic-N range $\S$ & $r^{2}$ \\
\hline \multirow{3}{*}{1} & & $\%$ & $\mathrm{~kg} \mathrm{ha}^{-1}$ & \\
\hline & Maize & $\begin{array}{l}\text { RY }=67+0.13 N_{0}-0.00015 N_{0}^{2} \\
R Y=95\end{array}$ & $\begin{array}{l}\text { for } N_{0}<441 \\
\text { for } N_{0}>441\end{array}$ & 0.97 \\
\hline & SorghumII & $\begin{array}{l}\mathbf{R Y}=56+0.15 \mathbf{N}_{\mathrm{o}} \\
\mathbf{R Y}=\mathbf{9 5}\end{array}$ & $\begin{array}{l}\text { for } \mathbf{N}_{0}<257 \\
\text { for } \mathbf{N}_{0}>\mathbf{2 5 7}\end{array}$ & 0.98 \\
\hline 2 & $\begin{array}{l}\text { Maize } \\
\text { Sorghum }\end{array}$ & $\begin{array}{l}\mathbf{R Y}=60+\mathbf{0 . 0 5 4} \mathbf{N}_{\mathrm{o}} \\
\mathbf{R Y}=49+\mathbf{0 . 0 8 1} \mathbf{N}_{\mathrm{o}}\end{array}$ & $\begin{array}{l}\text { for } N_{0}<744 \\
\text { for } N_{0}<634\end{array}$ & $\begin{array}{l}0.76 \\
0.82\end{array}$ \\
\hline 3 & $\begin{array}{l}\text { Maize } \\
\text { Sorghum }\end{array}$ & $\begin{array}{l}\text { RY }=55+0.025 \mathbf{N}_{0} \\
R Y=43+0.059 \mathbf{N}_{0}\end{array}$ & $\begin{array}{l}\text { for } N_{0}<1803 \\
\text { for } N_{0}<962\end{array}$ & $\begin{array}{l}0.85 \\
0.67\end{array}$ \\
\hline 4 & $\begin{array}{l}\text { Maize } \\
\text { Sorghum }\end{array}$ & $\begin{array}{l}\mathbf{R Y}=\mathbf{5 2}+\mathbf{0 . 0 2 1} \mathbf{N}_{\mathrm{o}} \\
\mathbf{R Y}=\mathbf{3 4}+\mathbf{0 . 0 2 9} \mathbf{N}_{\mathrm{o}}\end{array}$ & $\begin{array}{l}\text { for } \mathbf{N}_{\mathrm{p}}<2249 \\
\text { for } \mathbf{N}_{0}<2307\end{array}$ & $\begin{array}{l}0.74 \\
0.45\end{array}$ \\
\hline
\end{tabular}

$\dagger$ Year 1 refers to a crop grown in the year of biosolids application whereas years 2 to 4 refer to the number of years after a single biosolids application. Use the amount of organic $N$ applied the first year to determine the response 1, 2, and 3 years after application.

$\ddagger R Y=$ relative yield; $\mathbf{N}_{\mathbf{o}}=$ organic $\mathbf{N}$ input from biosolids $\left(\mathrm{kg} \mathrm{N} \mathrm{ha}^{-1}\right)$. To predict the quantity of grain, multiply the expected absolute yield by $R N / 100$.

$\S$ Valid range of the empirical models fitted. A plateau model described the typical yield response in Year 1 , whereas no RY plateau was reached within the range of biosolids rates tested for residual years.

II Response function fitted to the 1997 and 1998 data. Sorghum yield response to biosolids in 1996 (after soybean) was not significant. In the dry and cool year 1999, the response function was $R Y=32+0.14 N_{0}-0.00006 N_{0}^{2}$ for $N_{0}<689\left(R^{2}=0.98\right)$ and had no plateau within the range of measured data. 


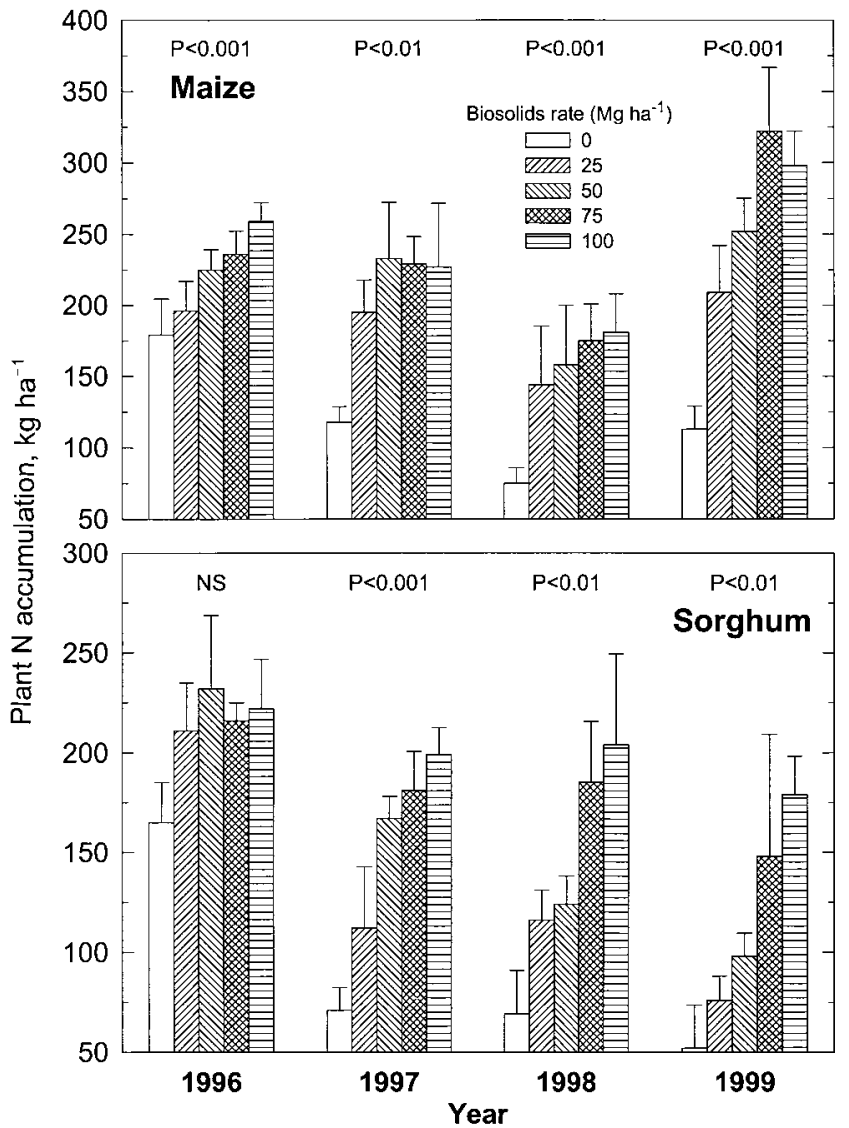

Fig. 5. Plant $\mathrm{N}$ accumulation at maturity of irrigated maize and rainfed sorghum as affected by the rate of applied biosolids in the year of application in 1996 to 1999 (Treatment means and standard deviation; $\boldsymbol{P}=$ probability of significant yield response). Biosolids rates shown in the legend refer to 1997 to 1999. In 1996, rates were $0,33,79,92$, and $106 \mathrm{Mg} \mathrm{ha}^{-1}$ for maize and $0,23,45,66$, and 90 $\mathrm{Mg} \mathrm{ha}^{-1}$ for sorghum.

lack of precipitation and irrigation during the critical pollination stage explained the lower grain yield with high $\mathrm{N}$ accumulation. Except for irrigated maize in 1999, however, the relationship between grain yield and $\mathrm{N}$ uptake by maize and sorghum was remarkably consistent and generally similar in biosolids- $\mathrm{N}$ and fertilizer$\mathrm{N}$ treatments (Fig. 6).

In irrigated maize, first-year $\mathrm{N}$ use efficiencies of biosolids-N decreased with increasing biosolids rate, but were similar to those of mineral $\mathrm{N}$ fertilizer applied at comparable $\mathrm{N}$ input levels (Tables 2 and 3 ). The average first-year $\mathrm{AE}_{\mathrm{N}}$ of biosolids-N applied in 1997 to 1999 was $18.3,10.9,7.2$, and $5.6 \mathrm{~kg} \mathrm{~kg}^{-1}$ for biosolids rates of $25,50,75$, and $100 \mathrm{Mg} \mathrm{ha}^{-1}$, respectively. Approximately $180 \mathrm{~kg} \mathrm{~N}^{-1}$ was applied in the $25 \mathrm{Mg} \mathrm{ha}^{-1}$ biosolids treatment in 1997 to 1999 and $\mathrm{AE}_{\mathrm{N}}$ ranged from 17 to $19 \mathrm{~kg} \mathrm{~kg}^{-1}$ (Table 2). A similar range of $\mathrm{AE}_{\mathrm{N}}$, 18 to $19 \mathrm{~kg} \mathrm{~kg}^{-1}$, was found from 1997 to 1999 in the $180 \mathrm{~kg} \mathrm{~N} \mathrm{ha}^{-1}$ mineral $\mathrm{N}$ treatment (Table 3). From 1997 to 1999 , average $\mathrm{RE}_{\mathrm{N}}$ in irrigated maize for the year of application was $0.42,0.29,0.24$, and $0.17 \mathrm{~kg}$ $\mathrm{kg}^{-1}$ for biosolids rates of $25,50,75$, and $100 \mathrm{Mg} \mathrm{ha}^{-1}$, respectively (Table 2). At similar $\mathrm{N}$ rates (i.e., $25 \mathrm{Mg}$ biosolids ha ${ }^{-1}$ in 1997 and 1998 vs 180 kg fertilizer-N

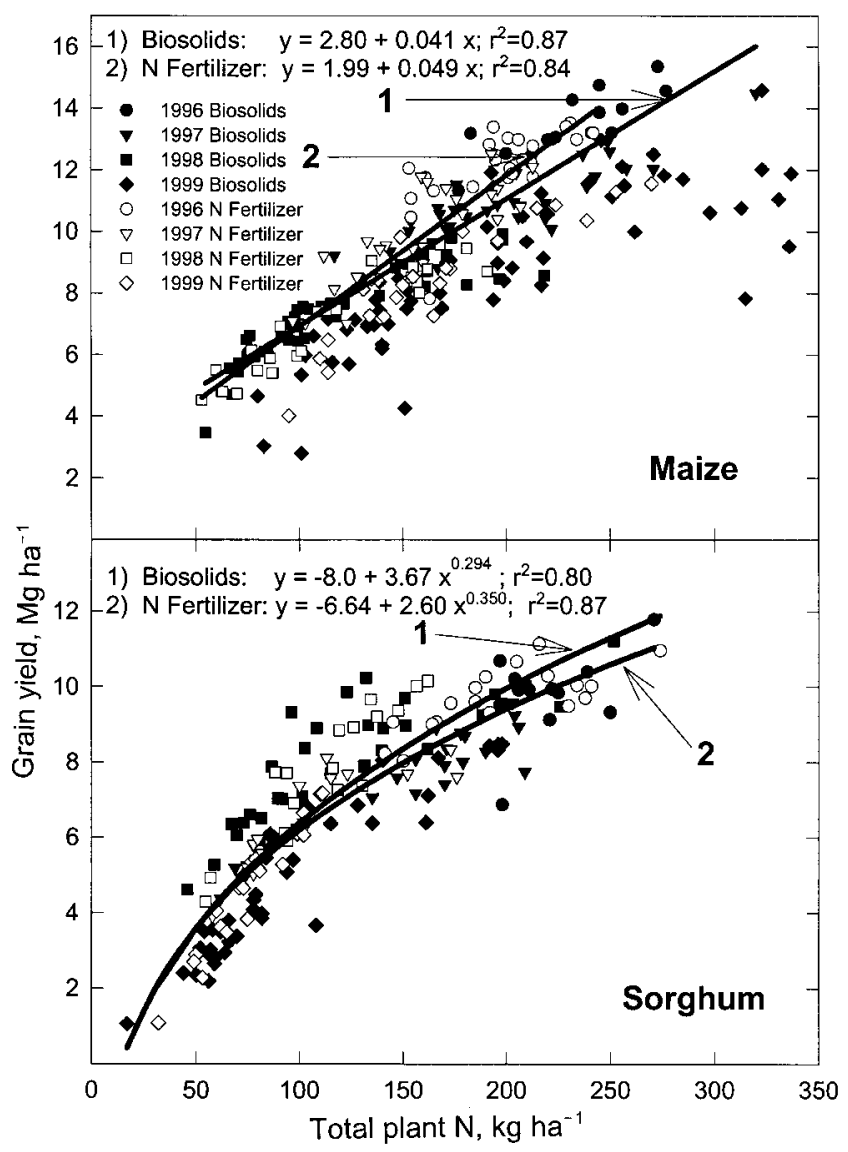

Fig. 6. Relationship between maize or sorghum grain yield and $\mathbf{N}$ accumulation in the total aboveground plant dry matter at physiological maturity, as affected by biosolids applied in the year of application or $\mathbf{N}$ fertilizer applied. Note that 1999 maize data were not included in the regression.

$\mathrm{ha}^{-1}$ in the same years) the $\mathrm{RE}_{\mathrm{N}}$ of biosolids-N was similar to that of $\mathrm{N}$ fertilizer $\left(0.37-0.45 \mathrm{~kg} \mathrm{~kg}^{-1}\right.$, Tables 2 and 3 ). In rainfed sorghum, $\mathrm{N}$ use efficiencies of biosolids- $\mathrm{N}$ were lower than those of mineral $\mathrm{N}$ fertilizer applied at comparable input levels (Tables 2 and 3). For example, in 1998, the $\mathrm{AE}_{\mathrm{N}}$ from $25 \mathrm{Mg}$ biosolids ha ${ }^{-1}$ was $12 \mathrm{~kg} \mathrm{~kg}^{-1}$ compared with $25 \mathrm{~kg} \mathrm{~kg}^{-1}$ from $150 \mathrm{~kg}$ fertilizer- $\mathrm{N} \mathrm{ha}{ }^{-1}$. In the same treatments, the $\mathrm{RE}_{\mathrm{N}}$ of biosolids- $\mathrm{N}$ was $0.30 \mathrm{~kg} \mathrm{~kg}^{-1}$, whereas that of inorganic $\mathrm{N}$ fertilizer was $0.48 \mathrm{~kg} \mathrm{~kg}^{-1}$. Excluding the nonresponsive initial year (1996), the first-year $\mathrm{AE}_{\mathrm{N}}$ of sorghum was 8 to 12,7 to 12,5 to 9 , and 4 to $6 \mathrm{~kg} \mathrm{~kg}^{-1}$ for biosolids rates of $25,50,75$, and $100 \mathrm{Mg} \mathrm{ha}^{-1}$, respectively. The $\mathrm{RE}_{\mathrm{N}}$ for the year of application ranged from 0.10 to $0.30,0.11$ to $0.24,0.09$ to 0.24 , and 0.08 to $0.21 \mathrm{~kg} \mathrm{~kg}^{-1}$ for the first, second, third, and fourth biosolids rates, respectively. Across all treatments and years, the average $\mathrm{RE}_{\mathrm{N}}$ of first year biosolids was $0.18 \mathrm{~kg} \mathrm{~kg}^{-1}$, whereas that of fertilizer-N was $0.41 \mathrm{~kg} \mathrm{~kg}^{-1}$. The $\mathrm{AE}_{\mathrm{N}}$ and $\mathrm{RE}_{\mathrm{N}}$ values estimated using the difference method (Eq. 1 and 2) mainly reflect the efficiency of biosolids $\mathrm{NH}_{4}-\mathrm{N}$ $(\approx 20 \%$ of total biosolids-N) plus a fraction of the organic- $\mathrm{N}$ mineralized during the first year. Irrigation likely increased $\mathrm{N}$ mineralization from biosolids as well as crop uptake, explaining the greater efficiency of bio- 


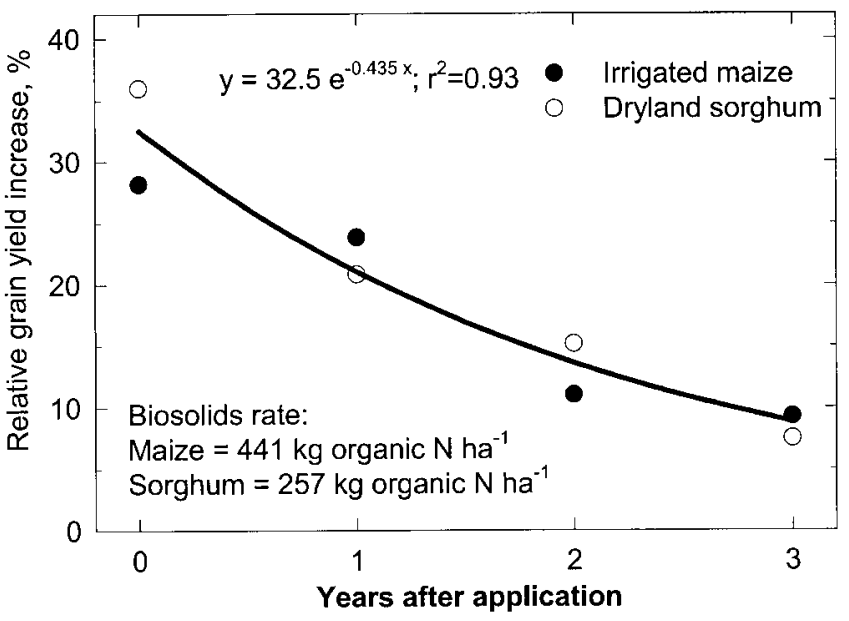

Fig. 7. Relative grain yield increase of irrigated maize and rainfed sorghum in comparison with an untreated control, as affected by the number of years after biosolids application. The biosolids rates used to generate this relationship were the optimal rates required to maximize yield in the year of application (Table 4).

solids- $\mathrm{N}$ in irrigated maize as compared with rainfed sorghum.

\section{Residual Effects of Biosolids on Yield, $\mathbf{N}$ uptake, and Soil Nitrate}

The residual response to applied biosolids was similar for both irrigated maize and rainfed sorghum when evaluated in terms of RY (Fig. 7). On average, the RY increase due to a one-time application of biosolids was $33 \%$ in the year of application, $21 \%$ in the second year, $14 \%$ in the third year, and $9 \%$ in the fourth year. Residual effects on yield would probably drop below detectable levels after $\approx 5 \mathrm{yr}$. The equations shown in Table 4 can be used to assess the decline in yield response as a function of the biosolids- $\mathrm{N}$ rate and year after application. For example, the predicted relative maize yield was 84,66 , and $61 \%$ of the maximum for the first, second, and third years after application when the optimal rate of $441 \mathrm{~kg}$ organic $\mathrm{N} \mathrm{ha}^{-1}$ was applied. The predicted relative sorghum grain yield was 70,58 , and $41 \%$ of the maximum for the first, second and third years after application when $257 \mathrm{~kg}$ organic $\mathrm{N} \mathrm{ha}^{-1}$ was applied. Despite the residual effect of biosolids, supplementary application of $\mathrm{N}$ fertilizer would also be required to maximize yield in the residual years.

In the subsequent years after biosolids application, additional $\mathrm{N}$ was recovered by the crops due to mineralization of organic biosolids- $\mathrm{N}$, but the relative cumulative $\mathrm{N}$ recovery depended on the biosolids rate (Table 2). For example, in the $25 \mathrm{Mg} \mathrm{ha}^{-1}$ biosolids rate applied in 1997, 1998, or 1999, maize recovered a total of $43 \%$ of the $\mathrm{N}$ applied in the first year, $58 \%$ after $2 \mathrm{yr}$, and $76 \%$ after 3 yr of cropping. This compares with cumulative $\mathrm{RE}_{\mathrm{N}}$ of $30(1 \mathrm{yr}), 42(2 \mathrm{yr})$, and $56 \%(3 \mathrm{yr})$ at a rate of $50 \mathrm{Mg}$ biosolids ha ${ }^{-1}$. The decrease in $\mathrm{RE}_{\mathrm{N}}$ with greater biosolids rates probably resulted from greater $\mathrm{N}$ losses from denitrification and leaching. Nitrogen recovery of fresh and residual biosolids- $\mathrm{N}$ was highest in

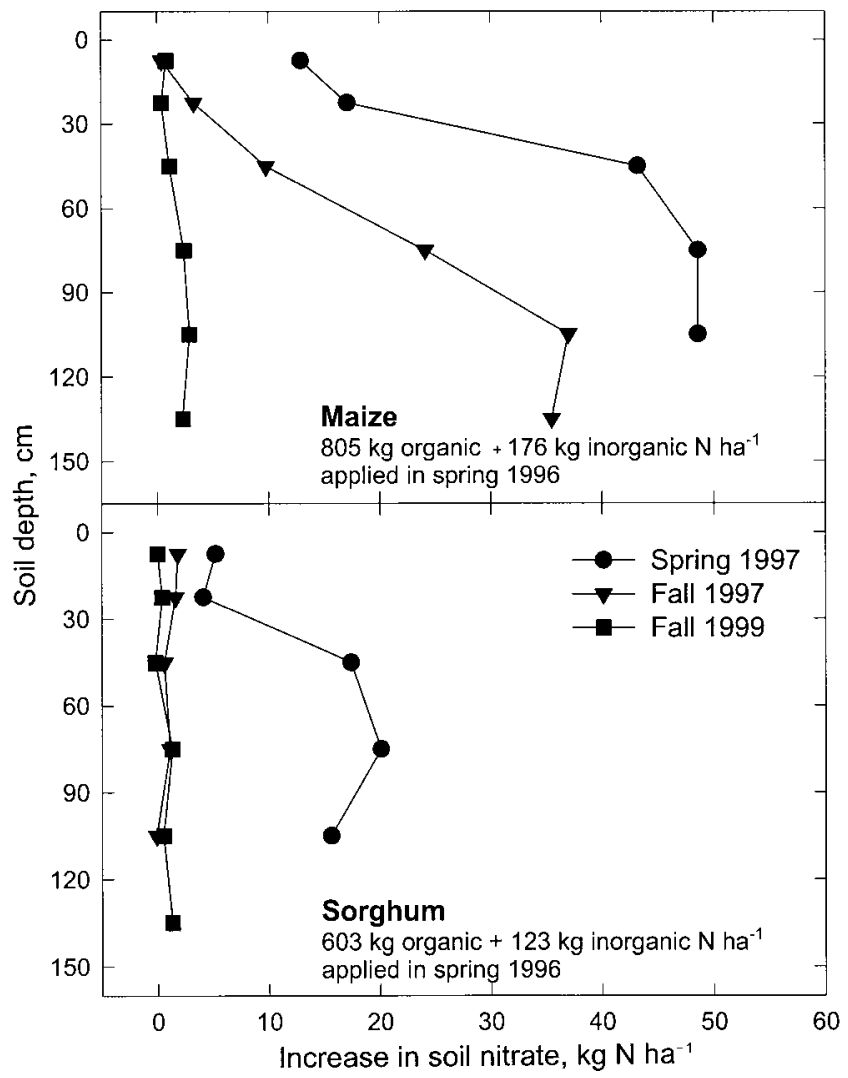

Fig. 8. Effect of a large biosolids application in spring 1996 on the increase in soil nitrate content above the untreated control from 1997 to 1999.

1999 due to the high $\mathrm{N}$ uptake observed in the biosolids treatments (Fig. 5). Water-filled pore space was $<50 \%$ during early growth in 1999 (data not shown), which probably minimized $\mathrm{N}$ losses and caused a build-up of mineral $\mathrm{N}$ during May and June, which was subsequently taken up by the maize plants with minimal leaching. At rates of 25 to $50 \mathrm{Mg}$ biosolids ha ${ }^{-1}, \approx 19 \%$ of the biosolids-N from 1997 to 1999 was recovered by sorghum in the first year, $32 \%$ in $2 \mathrm{yr}$, and $40 \%$ in $3 \mathrm{yr}$. Less $\mathrm{N}$ was mineralized and residual effects from biosolids lasted longer under rainfed conditions than under irrigated conditions.

One disadvantage to supplying multi-year crop $\mathrm{N}$ requirements with large single applications of biosolids is the potential for nitrate leaching or other $\mathrm{N}$ losses, particularly if the application rate exceeds the optimal rate required to maximize yield in the first year. At the irrigated maize site, $170 \mathrm{~kg} \mathrm{ha}{ }^{-1}$ more $\mathrm{NO}_{3} \mathrm{~N}$ than in the control had accumulated in the soil profile by spring 1997, when $981 \mathrm{~kg}$ biosolids-N ha ${ }^{-1}(805 \mathrm{~kg}$ organic $\mathrm{N}$, $176 \mathrm{~kg} \mathrm{NH}_{4}-\mathrm{N}$ ) was applied to maize in spring 1996 (Fig. 8). By fall 1997, $>110 \mathrm{~kg} \mathrm{ha}^{-1}$ more $\mathrm{NO}_{3} \mathrm{~N}$ than in the control were measured in the 0 - to $150-\mathrm{cm}$ soil depth, but $3 \mathrm{yr}$ after biosolids application, soil $\mathrm{NO}_{3}$ levels were similar to soil that had not received biosolids. The $\mathrm{NO}_{3}$ accumulated in the previous years had either been lost from the root zone by leaching or gaseous loss processes or was utilized by maize. Nitrogen budget calculations 
Table 5. Nitrogen budget in treatments that received single biosolids applications in spring 1996. All values shown are the difference between + biosolids treatments and the control treatments without biosolids application.

\begin{tabular}{|c|c|c|c|c|c|c|c|}
\hline \multirow[b]{2}{*}{ Biosolids } & \multirow[b]{2}{*}{$\begin{array}{l}\text { Total N } \\
\text { applied }\end{array}$} & \multicolumn{3}{|c|}{$\mathbf{N}$ budget in spring 1997 (after one crop) } & \multicolumn{3}{|c|}{$\mathbf{N}$ budget in fall 1999 (after four crops) } \\
\hline & & $\begin{array}{l}\text { Increase in } \\
\text { crop removal }\end{array}$ & $\begin{array}{c}\text { Increase in } \\
\mathrm{NO}_{3}-\mathbf{N} \dagger\end{array}$ & $\begin{array}{c}\text { Unaccounted } \\
\mathbf{N} *\end{array}$ & $\begin{array}{l}\text { Increase in } \\
\text { crop removal }\end{array}$ & $\begin{array}{c}\text { Increase in } \\
\mathrm{NO}_{3}-\mathbf{N} \dagger\end{array}$ & $\begin{array}{c}\text { Unaccounted } \\
\mathrm{N}_{\dagger}\end{array}$ \\
\hline \multirow[t]{2}{*}{$\mathrm{Mg} \mathrm{ha}^{-1}$} & \multirow{2}{*}{\multicolumn{7}{|c|}{$\begin{array}{l}- \text { kg } \mathbf{N} \text { ha }^{-1} \\
\text { Irrigated Maize }\end{array}$}} \\
\hline & & & & & & & \\
\hline 33 & 305 & 17 & 9 & $279(91 \%)$ & 259 & - & - \\
\hline 79 & 731 & 46 & 50 & $635(87 \%)$ & 383 & $-\mathbf{3}$ & $351(48 \%)$ \\
\hline 92 & 851 & 57 & 70 & $724(85 \%)$ & 477 & - & - \\
\hline \multirow[t]{2}{*}{106} & 981 & 80 & 170 & $731(74 \%)$ & 480 & 8 & $493(50 \%)$ \\
\hline & \multicolumn{6}{|c|}{ Rainfed Sorghum } & \\
\hline 23 & 188 & 46 & 12 & $130(69 \%)$ & 158 & - & - \\
\hline 45 & 358 & 67 & 20 & $271(76 \%)$ & 264 & 12 & $82(23 \%)$ \\
\hline 66 & 527 & 51 & 37 & $439(83 \%)$ & 373 & - & - \\
\hline 90 & 726 & 57 & 62 & $607(84 \%)$ & 447 & 3 & $276(38 \%)$ \\
\hline
\end{tabular}

$\dagger$ Soil $\mathrm{NO}_{3}-\mathrm{N}$ in a 0 - to $120-\mathrm{cm}$ depth, increase or decrease over control plot.

+ $\mathbf{N}$ unaccounted for by crop removal and residual soil nitrate $=\mathbf{N}$ applied $-($ crop removal + residual $\mathbf{N})$. Includes biosolids- $\mathbf{N}$ that remains unmineralized, biosolids- $\mathbf{N}$ converted into soil organic matter, and biosolids- $\mathbf{N}$ that was lost due to leaching or gaseous losses. Numbers in parenthesis show the percentage of unaccounted $N$ of the total amount of biosolids- $N$ applied in spring 1996.

indicated that $1 \mathrm{yr}$ after application, maize $\mathrm{N}$ uptake and residual $\mathrm{NO}_{3}-\mathrm{N}$ accounted for 9 to $26 \%$ of biosolids$\mathrm{N}$ applied in 1996 (Table 5). After four crops, in treatments with biosolids rates that exceeded the optimal rate required to maximize yield in the year of application (Fig. 4), $\approx 50 \%$ of the total $\mathrm{N}$ applied was not accounted for by either crop uptake or residual $\mathrm{NO}_{3}-\mathrm{N}$ in the soil. However, there was very little additional $\mathrm{NO}_{3}$ accumulation when biosolids were applied at rates lower or close to the recommended rate for maximizing yield. For example, differences in residual soil $\mathrm{NO}_{3}$ between + biosolids treatments and the control measured in fall 1999 (0 to $150 \mathrm{~cm}$ soil depth) were $-3 \mathrm{~kg} \mathrm{~N} \mathrm{ha}^{-1}$ at a biosolids rate of $177 \mathrm{~kg}$ organic-N ha ${ }^{-1}$ or $17 \mathrm{~kg} \mathrm{~N} \mathrm{ha}^{-1}$ at 353 kg organic-N ha-1 applied in spring 1999 (Fig. 9).

Less $\mathrm{NO}_{3}$ accumulated in the soil and less $\mathrm{N}$ remained unaccounted for at the rainfed sorghum site, which is consistent with the hypothesis that $\mathrm{N}$ mineralization of biosolids- $\mathrm{N}$ was slower and leaching losses were smaller under rainfed than irrigated conditions. About $62 \mathrm{~kg}$ additional $\mathrm{NO}_{3} \mathrm{~N} \mathrm{ha}^{-1}$ had accumulated in the 0- to $120-\mathrm{cm}$ soil depth by the spring of 1997 , when a heavy dose of $726 \mathrm{~kg} \mathrm{~N} \mathrm{ha}^{-1}$ (603 kg organic N, $123 \mathrm{~kg}$ ammonium N) was applied to sorghum in spring 1996 (Fig. 8). However, soil $\mathrm{NO}_{3}$ levels had already decreased by fall 1997 and remained at levels similar to the control until fall 1999. Depending on the biosolids rate, 16 to $31 \%$ of biosolids-N applied in spring 1996 was recovered by sorghum $\mathrm{N}$ uptake or residual soil $\mathrm{NO}_{3}$ after $1 \mathrm{yr}$ (Table 5). However, this proportion increased to 62 to $77 \%$ after $4 \mathrm{yr}$ in the two treatments for which $4-\mathrm{yr} \mathrm{NO}_{3}$ measurements were available. As for maize, at biosolids rates close to those required to maximize sorghum yields, the potential for $\mathrm{NO}_{3}$ accumulation and $\mathrm{N}$ losses such as leaching was small. For example, differences in residual soil $\mathrm{NO}_{3}$ between + biosolids treatments and the control measured in fall 1999 (0 to $150 \mathrm{~cm}$ soil depth) were $10 \mathrm{~kg} \mathrm{~N} \mathrm{ha}^{-1}$ at a biosolids rate of $185 \mathrm{~kg}$ organic$\mathrm{N} \mathrm{ha}^{-1}$ as compared with $40 \mathrm{~kg} \mathrm{~N} \mathrm{ha}^{-1}$ at $556 \mathrm{~kg}$ organic$\mathrm{N} \mathrm{ha}{ }^{-1}$ applied in spring 1999 (Fig. 9).

It is impossible to accurately attribute $\mathrm{N}$ unaccounted for by crop uptake or residual $\mathrm{NO}_{3}$ to specific processes such as leaching, denitrification, immobilization in organic matter, or residual biosolids-N. However, the quick accumulation of nitrate in soil depths below 30 $\mathrm{cm}$ and the greater amount of $\mathrm{N}$ unaccounted for at the irrigated site indicate that leaching was a major process, particularly with irrigation and if biosolids rates exceeded crop N demand by a large margin. Further evidence for this is provided by comparing the fate of biosolids- $\mathrm{N}$ in the two treatments that received almost identical amounts of 731 (maize) or 726 (sorghum) kg biosolids- $\mathrm{N} \mathrm{ha}^{-1}$ in 1996 (Table 5). After $4 \mathrm{yr}$, residual soil $\mathrm{NO}_{3}$ levels at both sites were similar to the control in both treatments, but crop uptake accounted for $62 \%$ (sorghum) or $52 \%$ (maize) of the $\mathrm{N}$ applied to sorghum, suggesting that $\approx 70 \mathrm{~kg} \mathrm{~N}^{-1}$ more had been lost under irrigated maize as compared with rainfed sorghum. Gaseous losses of $\mathrm{N}_{2} \mathrm{O}$ or $\mathrm{N}_{2}$ probably occurred, but further research will be required to clarify their importance with regard to biosolids applications. Microbial activity leading to $\mathrm{N}_{2}$ and trace gas emissions are closely related to soil moisture, $\mathrm{NO}_{3}$ concentrations, available $\mathrm{C}, \mathrm{pH}$ and electrical conductivity in soil solution (Stanford et al., 1975; McCormick and Wolf, 1980; Nugroho and Kuwatsuka, 1992; Weier et al., 1993). Biosolids application is likely to influence many of these processes.

\section{Economic Value}

Only a partial economical assessment can be performed because, at our site, biosolids were hauled to farmers' fields at no cost to the farmer. Production, storage, and transport of biosolids were covered by the wastewater treatment plant, which in turn covers this cost from revenues generated within its service area. Our analysis below only assesses the potential benefits to a farmer at a biosolids rate of $62 \mathrm{Mg} \mathrm{ha}^{-1}$ (irrigated maize) or $36 \mathrm{Mg} \mathrm{ha}^{-1}$ (rainfed sorghum). It is not valid for biosolids rates that exceed the amount required to maximize yields in the year of application, that is, rates at which crop response is less certain and additional environmental costs must be factored in. Also, these 


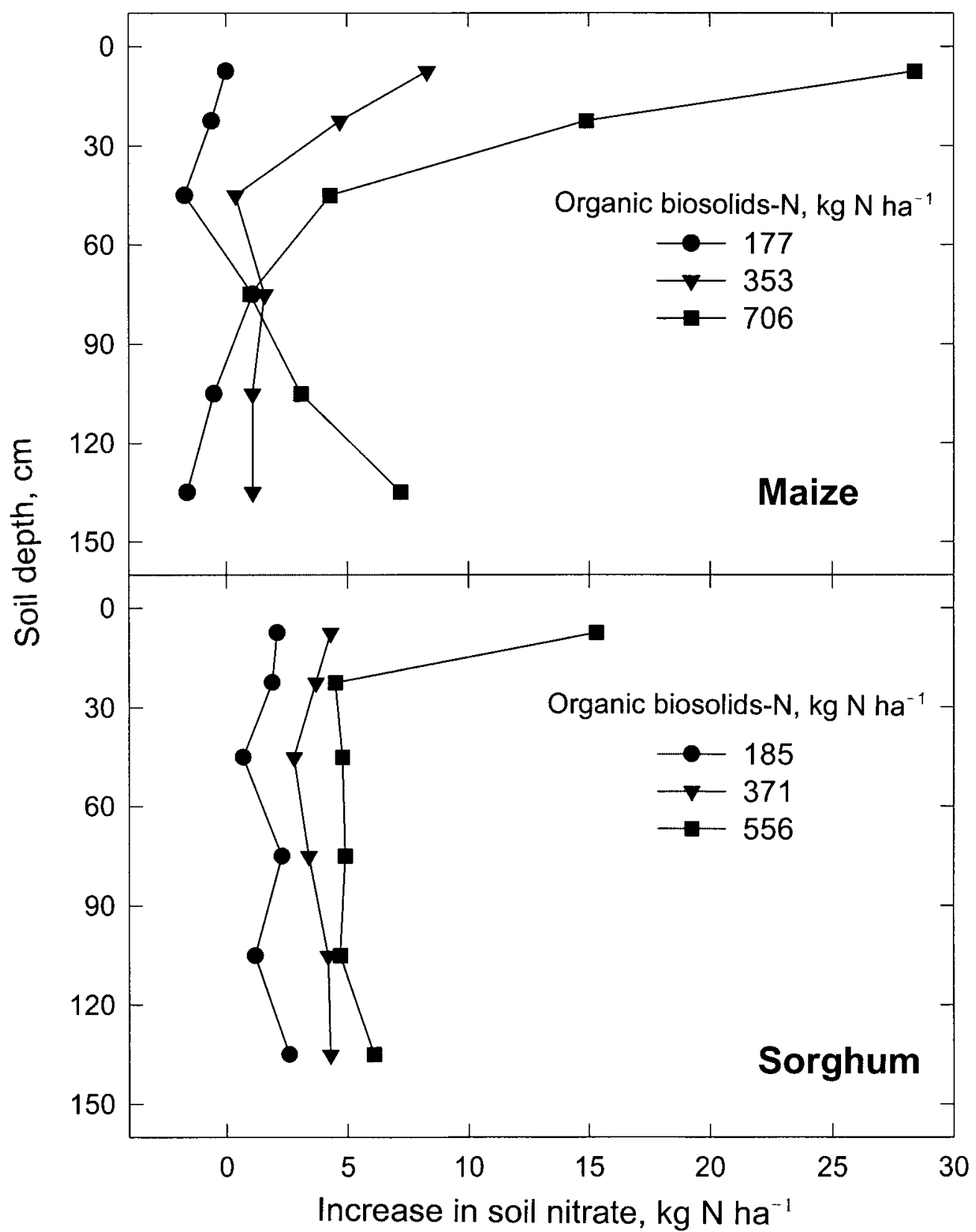

Fig. 9. Soil nitrate increase above the untreated control, as affected by the amount of biosolids organic-N. Biosolids were applied in spring 1999. The soil nitrate distribution shown was measured in the fall of 1999.

estimates of economic benefits are subject to climate variability or other factors, which affect crop performance such as water supply and pests.

In irrigated maize, $\approx 530 \mathrm{~kg} \mathrm{~N}^{-1}$ would be applied once with the $62 \mathrm{Mg} \mathrm{ha}^{-1}$ biosolids, resulting in a $28 \%$ yield increase over an unfertilized control in the year of application. To achieve the same yield increase, 211 $\mathrm{kg}$ inorganic $\mathrm{N} \mathrm{ha}^{-1}$ had to be applied at a fertilizer cost of $\$ 70 \mathrm{ha}^{-1}$ (Table 6). In rainfed sorghum, an application of $36 \mathrm{Mg} \mathrm{ha}{ }^{-1}$ was equivalent to $\$ 36 \mathrm{ha}^{-1}$ in terms of $\mathrm{N}$ fertilizer value. Including the residual benefits in subsequent years, the cumulative $\mathrm{N}$ fertilizer value of a single biosolids application in a 4-yr period was estimated to be $\$ 136 \mathrm{ha}^{-1}$ for irrigated maize and $\$ 68 \mathrm{ha}^{-1}$ for rainfed sorghum (Table 6). For the whole 4-yr period, biosolids had a total $\mathrm{N}$ value of $\$ 2.2 \mathrm{Mg}^{-1}$ in maize or $\$ 1.9 \mathrm{Mg}^{-1}$ in sorghum. However, the fertilizer equivalent declined from 3 to $3.4 \mathrm{~kg} \mathrm{~N} \mathrm{Mg}^{-1}$ biosolids in the first year to $0.4 \mathrm{~kg} \mathrm{~N} \mathrm{Mg}^{-1}$ biosolids in the fourth year.

Economic benefits from a single biosolids application can only be fully realized if $\mathrm{N}$ application is adjusted by supplementary fertilizer- $\mathrm{N}$ to account for the declining residual $\mathrm{N}$ contribution from biosolids across time. More research is required to design crop rotations that efficiently use $\mathrm{N}$ that accumulates throughout the whole root zone. Differences among crops appear to exist in their ability to utilize biosolids-N, which are probably related to differences in the root system. For example, 
Table 6. Cumulative nitrogen fertilizer value of biosolids when applied to irrigated maize and dryland sorghum at the rate to maximize yields in the first year. Values shown refer to a biosolids application of $62 \mathrm{Mg} \mathrm{ha}^{-1}$ to maize or $36 \mathrm{Mg} \mathrm{ha}^{-1}$ to sorghum.

\begin{tabular}{|c|c|c|c|c|c|c|c|}
\hline Crop no. & $\begin{array}{c}\text { (A) } \\
\mathbf{N} \text { input } \\
\text { from } \\
\text { biosolids } \dagger\end{array}$ & $\begin{array}{c}\text { (B) } \\
\text { Relative yield } \\
\text { increase from } \\
\text { biosolids } \$\end{array}$ & $\begin{array}{l}\text { (C) } \\
\text { Fertilizer N } \\
\text { required } \$\end{array}$ & $\begin{array}{c}\text { (D) } \\
\text { Available } \\
\text { biosolids NI }\end{array}$ & $\begin{array}{c}\text { (E) } \\
\text { Value of } \\
\text { fertilizer } N \#\end{array}$ & $\begin{array}{c}\text { (F) } \\
\text { Fertilizer } \\
\text { equivalent }+\dagger\end{array}$ & $\begin{array}{c}\text { (G) } \\
\mathbf{N} \text { value of } \\
\text { biosolids }\end{array}$ \\
\hline & $\operatorname{kg~N}$ ha $^{-1}$ & $\%$ & kg N ha ${ }^{-1}$ & $\%$ & $\$ h^{-1}$ & $\mathbf{k g ~ N ~} \mathbf{M g}^{-1}$ & $\$ \mathbf{M g}^{-1}$ \\
\hline \multicolumn{8}{|c|}{ Irrigated maize } \\
\hline 1 & $\mathbf{5 3 2}$ & 28 & 211 & 40 & 70 & 3.4 & 1.12 \\
\hline 2 & 0 & 24 & 143 & 27 & 47 & 2.3 & 0.76 \\
\hline 3 & 0 & 11 & 39 & 7 & 12 & 0.6 & 0.19 \\
\hline 4 & 0 & 9 & 22 & 4 & 7 & 0.4 & 0.12 \\
\hline Total & 532 & & 415 & 78 & 136 & 6.7 & 2.19 \\
\hline \multicolumn{8}{|c|}{ Rainfed sorghum } \\
\hline 1 & 309 & 36 & 108 & 39 & 36 & 3.0 & 0.99 \\
\hline 2 & 0 & 21 & 51 & 17 & 17 & 1.4 & 0.47 \\
\hline 3 & 0 & 15 & 33 & 11 & 11 & 0.9 & 0.30 \\
\hline 4 & 0 & 7 & 13 & 4 & 4 & 0.4 & 0.12 \\
\hline Total & 309 & & 205 & 71 & 68 & 5.7 & 1.88 \\
\hline
\end{tabular}

$\dagger$ Assuming $18.5 \%$ dry matter, $38 \mathrm{~g}$ organic- $\mathrm{N} \mathrm{kg}^{-1}$ dry matter, and $8.4 \mathrm{~g}$ inorganic $\mathrm{N} \mathrm{kg}^{-1}$ dry matter.

+ Average relative yield increase from a single biosolids application in Year 1, see Fig. 6 .

$\$$ Amount of fertilizer-N (FN) needed to achieve an increase in relative yield (iRY, \%) equivalent to that from biosolids $\mathbf{N}$ (column B). On the basis of $\mathrm{N}$ response curves fitted to the data shown in Table 2: irrigated maize: $\mathrm{iRY}=5.17+0.18 \mathrm{FN}-0.00034 \mathrm{FN}^{2}\left(\right.$ average of 1996 to 1999, $\left.R^{2}=0.90\right)$ rainfed sorghum: iRY $=1.62+0.44 \mathrm{FN}-0.00113 \mathrm{FN}^{2}$ (average of 1997 to $1999, R^{2}=0.98$ ).

II Estimate of \% of plant available $\mathbf{N}$ from biosolids. (D) = (C)/amount of biosolids-N applied in Year 1 (A).

$\#(E)=(C) \times \$ 0.33 \mathbf{~ k g}^{-1}$ fertilizer-N (assumed average price of fertilizer $N$ ).

$\dagger \mathrm{kg} \mathrm{N}$ per Mg fresh biosolids. (F) $=(\mathrm{C}) / 62 \mathrm{Mg} \mathrm{ha}^{-1}$ in maize or (C)/36 $\mathrm{Mg} \mathrm{ha}^{-1}$ in sorghum.

ft \# per Mg fresh biosolids. (G) $=(\mathrm{F}) \times \$ 0.33 \mathrm{~kg}^{-1}$ fertilizer-N (assumed average price of fertilizer $\mathrm{N}$ ).

a rotation of irrigated maize plus biosolids in Year 1, sorghum in Year 2, and soybean in Year 3 would probably not require any extra $\mathrm{N}$ fertilizer and ensure maximum use of biosolids- $\mathrm{N}$ at minimum $\mathrm{NO}_{3}$ accumulation in the soil profile. Research is also required to quantify long-term effects of biosolids use on elements other than $\mathrm{N}$ and soil and water quality at scales of entire watersheds in the vicinity of larger cities.

\section{CONCLUSIONS}

Anaerobically digested sewage sludges (biosolids) have a high agronomic value. A sustainable biosolids management strategy must ensure (i) high yields and profit, and (ii) minimize the accumulation of $\mathrm{NO}_{3}, \mathrm{P}$, and other elements in the soil. In our study, benefits of biosolids application in terms of $\mathrm{N}$ use efficiency and profit were greatest in irrigated systems where crop growth was less likely to be limited by factors such as water supply. Biosolids amounts required to maximize yields in the year of application on a silty clay loam were $62 \mathrm{Mg} \mathrm{ha}^{-1}$ in irrigated maize and $36 \mathrm{Mg} \mathrm{ha}^{-1}$ in rainfed sorghum. At biosolids application rates required to maximize yields in the year of application, $\mathrm{NO}_{3}$ accumulation was small in both crops and first-year $\mathrm{N}$ use efficiency of biosolids- $\mathrm{N}$ was comparable to fertilizer$\mathrm{N}$ applied to irrigated maize. However, as with other fertilizers, there is a significant threat of $\mathrm{NO}_{3}$ leaching or gaseous emissions if biosolids rates exceed the optimal amount, particularly in irrigated systems.

About $80 \%$ of the biosolids- $\mathrm{N}$ was in organic forms and much of this was mineralized across a period of 4 yr. The proportion of total biosolids-N available in each year after a single application was similar for maize and sorghum when biosolids were applied at rates high enough to maximize yield in the first year. Because contributions of organic and mineral biosolids- $\mathrm{N}$ to crop uptake are difficult to separate, practical rate recommendations for biosolids use should be based on the total $\mathrm{N}$ input and its potential cumulative plant recovery and leaching potential across a period of $\approx 4$ yr. For agronomic purposes such as fertilizer plans, $\approx 40,20,10$, and $5 \%$ of the total biosolids-N (organic + inorganic) were available to crops in the first, second, third, and fourth year, respectively. These field-based estimates were larger than current guidelines on biosolids- $\mathrm{N}$ mineralization (USEPA, 1995), which are often based on laboratory studies.

For optimal performance, actual biosolids rates should be further adjusted depending on soil organic matter content, initial soil $\mathrm{NO}_{3}$, yield goal, and biosolids composition. Supplementary $\mathrm{N}$ fertilizer is required in the year of application if the biosolids rate is below the rate required to maximize yields and in years following a biosolids application. This is especially important in irrigated systems with high yield potential.

\section{ACKNOWLEDGMENTS}

A special thanks goes to Ken Frank for his involvement with our program and his technical assistance. We thank the City of Lincoln's Public Works and Utilities Department for their financial and technical support of this project. In addition, the authors would like to thank the Lancaster County Extension Office personnel, especially Warder Shires, involved with land applying biosolids, and the farmers cooperating with us in this project.

\section{REFERENCES}

American Public Health Association. 1995. Standard methods for the examination of water and wastewater. 19th ed. APHA, Washington, DC.

Artiola, J.F., and I.L. Pepper. 1992. Long-term influence of liquid sewage sludge on the organic carbon and nitrogen content of a furrow-irrigated desert soil. Biol. Fertil. Soils 14:30-36. 
Barbarick, K.A., J.A. Ippolito, and D.G. Westfall. 1996. Distribution and mineralization of biosolids nitrogen applied to dryland wheat. J. Environ. Qual. 25:796-801.

Boyle, M., and E.A. Paul. 1989. Carbon and nitrogen mineralization kinetics in soil previously amended with sewage sludge. Soil Sci. Soc. Am. J. 53:99-103.

Bray, R.H., and L.T. Kurtz. 1945. Determination of total organic and available phosphorus in soils. Soil Sci. 59:39-45.

Brown, J.R., and D. Warncke. 1988. Recommended cation tests and measures of cation exchange capacity. p. 15-16. In Recommended chemical soil test procedures for the North Central Region. North Central Region Publ. no. 221. North Dakota State Univ., Fargo, ND.

Chae, Y.M., and M.A. Tabatabai. 1986. Mineralization of nitrogen in soils amended with organic wastes. J. Environ. Qual. 15:193-198.

Gilmour, J.T., and C.M. Gilmour. 1980. A simulation model for sludge decomposition in soil. J. Environ. Qual. 9:194-199.

Goldstein, N. 1997. State biosolids management update. BioCycle 97: 62-66.

Hinesly, T.D., R.L. Jones, and E.L. Ziegler. 1972. Effects on corn by applications of heated anaerobically digested sludge. Compost Sci. 13:26-30.

Janssen, B.H., F.C.T. Guiking, D. Van der Eijk, E.M.A. Smaling, J. Wolf, and H. van Reuler. 1990. A system for Quantitative Evaluation of the Fertility of Tropical Soils (QUEFTS). Geoderma 46: 299-318.

Keeney, D.R. 1989. Sources of nitrate to groundwater. p. 23-34. In R.F Follett (ed.) Nitrogen management and ground water protection. Elsevier Applied Science, New York.

Keeney, D.R., K.W. Lee, and L.M. Walsh. 1975. Guidelines for the application of wastewater sludge to agricultural land in Wisconsin. 88th ed. Wisconsin Dep. Nat. Resources, Madison, WI.

Kelling, D.A., A.E. Perterson, L.M. Walsh, J.A. Ryan, and D.R Keeney. 1977a. A field study of agricultural use of sewage sludge: I. Effect on crop yield and uptake of N and P. J. Environ. Qual. 6:339-345.

Kelling, D.A., A.E. Perterson, L.M. Walsh, J.A. Ryan, and D.R. Keeney. 1977b. A field study of agricultural use of sewage sludge: II. Effect on soil N and P. J. Environ. Qual. 6:345-352.

Klausner, S.D., V.R. Kanneganti, and D.R. Bouldin. 1994. An approach for estimating a decay series for organic nitrogen in animal manure. Agron. J. 86:897-903.

Lerch, R.N., K.A. Barbarick, D.G. Westfall, R.H. Follett, T.M. McBride, and W.F. Owen. 1990. Sustainable rates of sewage sludge for dryland winter wheat production II. Production and income. J. Prod. Agric. 3:66-71.

Lindemann, W.C., and M. Cardenas. 1984. Nitrogen mineralization potential and nitrogen transformations of sludge-amended soil. Soil Sci. Soc. Am. J. 48:1072-1077.

Lindsay, W.L., and W.A. Norvell. 1978. Development of a DTPA soil test for zinc, iron, manganese and copper. Soil Sci. Soc. Am. J. 42:421-428.

Mathers, A.C., and D.W. Goss. 1979. Estimating animal waste applications to supply crop requirements. Soil Sci. Soc. Am. J. 43:364-366.

McCormick, R.W., and D.C. Wolf. 1980. Effect of sodium chloride on $\mathrm{CO}_{2}$ evolution, ammonification, and nitrification in a Sassafras sandy loam. Soil Biol. Biochem. 12:153-157.
McGeehan, S.L., and D.V. Naylor. 1988. Automated instrumental analysis of carbon and nitrogen in plant and soil samples. Commun. Soil Sci. Plant Anal. 19:493-505.

Mulvaney, R.L. 1996. Nitrogen-Inorganic forms. p. 1123-1185. In D.L. Sparks et al. (ed.) Methods of soil analysis. Part 3. Chemical methods. SSSA Book Ser. 5. SSSA and ASA, Madison, WI.

Nelson, D.W., and C.A. Shapiro. 1989. Fertilizing crops with animal manure. Ext. Circ. 89-117. Univ. of Nebraska, Lincoln, NE.

Nugroho, S.G., and S. Kuwatsuka. 1992. Concurrent observation of several processes of nitrogen metabolism in soil amended with organic materials. V. Effects of long-term application of farmyard manure and nitrogen fertilizer on $\mathrm{N}$ cycling processes in upland field soil. Soil Sci. Plant Nutr. (Tokyo) 38:619-629.

Oberle, S.L., and D.R. Keeney. 1994. Interactions of sewage sludge with soil-crop-water systems. p. 17-20. In C.E. Clapp et al. (ed.) Sewage sludge: Land utilization and the environment. ASA, CSSA, SSSA, Madison, WI.

Parker, C.F., and L.E. Sommers. 1983. Mineralization of nitrogen in sewage sludge. J. Environ. Qual. 12:150-156.

Pierzynski, G.M. 1994. Plant nutrient aspects of sewage sludge. p. 21-25. In C.E. Clapp et al. (ed.) Sewage sludge: Land utilization and the environment. ASA, CSSA, SSSA, Madison, WI.

SAS Institute. 1988. SAS/STAT User's guide. Release 6.03. SAS Inst., Cary, N.C.

Sims, J.T., and F.C. Boswell. 1980. The influence of organic wastes and inorganic nitrogen sources on soil nitrogen, yield, and elemental composition of corn. J. Environ. Qual. 9:512-518.

Sommers, L.E. 1977. Chemical composition of sewage sludges and analysis of their potential use as fertilizers. J. Environ. Qual. 9: 225-232.

Stanford, G., R.A. Van der Pol, and S. Dzienia. 1975. Denitrification rates in relation to total and extractable soil carbon. Soil Sci. Soc. Am. Proc. 39:284-289.

Stewart, N.E., E.G. Beauchamp, C.T. Corke, and L.R. Webber. 1975 Nitrate nitrogen distribution in corn following applications of digested sewage sludge. Can. J. Soil Sci. 55:287-294.

Sullivan, D.M., S.C. Fransen, C.G. Cogger, and A.I. Bary. 1997. Biosolids and dairy manure as nitrogen sources for prairiegrass on a poorly drained soil. J. Prod. Agric. 10:589-596.

USEPA. 1993. Standards for use or disposal of sewage sludge. Federal Register 58:9248-9415. U.S. Gov. Print. Office, Washington, DC.

USEPA. 1995. Process design manual: Land application of sewage sludge and domestic septage. USEPA Rep. 625/R-95/001. U.S. Gov. Print. Office, Washington, DC.

Walkley, A. 1947. A critical examination of a rapid method for determining organic carbon in soils: Effect of variations in digestion conditions and of inorganic soil constituents. Soil Sci. 63:251-263.

Weier, K.L., J.W. Doran, J.F. Power, and D.T. Walters. 1993. Denitrification and the dinitrogen/nitrous oxide ratio as affected by soil water, available carbon, and nitrate. Soil Sci. Soc. Am. J. 57:66-72.

Witt, C., A. Dobermann, S. Abdulrachman, H.C. Gines, G.H. Wang, R. Nagarajan, S. Satawathananont, T.T. Son, P.S. Tan, L.V. Tiem, G.C. Simbahan, and D.C. Olk. 1999. Internal nutrient efficiencies of irrigated lowland rice in tropical and subtropical Asia. Field Crops Res. 63:113-138.

Yeomans, J.C., and J.M. Bremner. 1991. Carbon and nitrogen analysis of soils by automated combustion technique. Commun. Soil Sci. Plant Anal. 22:843-850. 